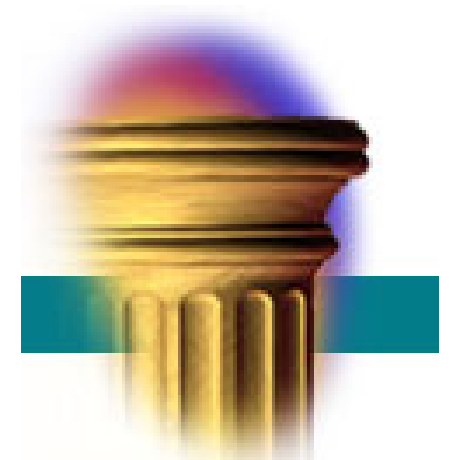

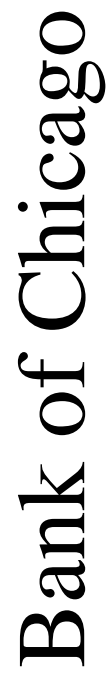

Access to Refinancing and Mortgage Interest Rates: HARPing on the Importance of Competition

Gene Amromin and Caitlin Kearns

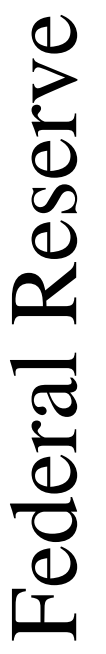

November 2014

WP 2014-25 


\title{
Access to Refinancing and Mortgage Interest Rates: HARPing on the Importance of Competition
}

\author{
Gene Amromin \\ Federal Reserve Bank of Chicago \\ Caitlin Kearns \\ University of California - Berkeley
}

November 30, 2014

\begin{abstract}
We explore a policy-induced change in borrower ability to shop for mortgages to investigate whether market competitiveness affects mortgage interest rates. Our paper exploits a discontinuity in the competitive landscape introduced by the Home Affordable Refinancing Program (HARP). Under HARP, lenders that currently service loans eligible for refinancing enjoyed substantial advantages over their potential competitors. Using a fuzzy regression discontinuity design, we show a jump in mortgage interest rates precisely at the HARP eligibility threshold. Our results suggest that limiting competition raised interest rates on 30-year fixed-rate mortgages by 15 to 20 basis points, translating into higher lender profits. The results are distinct from documented effects of consolidation and capacity reduction in mortgage lending and are robust to a number of sample restrictions and estimation choices. We interpret our findings as evidence that increases in pricing power lead to higher interest rates in mortgage markets.
\end{abstract}

We thank Jeff Campbell, Janice Eberly, Laurie Goodman, and Carl Shapiro for many helpful discussions. Mike Mei provided expert research assistance. The views expressed here are those of the authors and do not necessarily represent those of the Federal Reserve Bank of Chicago or the Federal Reserve System. 


\section{Introduction}

In times of recessions, countercyclical monetary policy actions of central banks provide relief to borrowers by lowering their interest costs. In the household sector, where housing debt represents the largest financial obligation, mortgage loans serve as a key conduit for lower interest rates. In countries where mortgage contracts typically take the form of adjustable rate loans (ARMs), the transmission of monetary policy actions is nearly automatic (Badarinza, Campbell, and Ramadorai 2014). In the United States, where the majority of mortgage loans are fixed-rate contracts, borrowers can take advantage of lower interest rates by paying off their existing loans and taking out new ones. However, the ability to refinance an existing loan depends directly on borrower's creditworthiness and on having sufficient equity in the house, both of which are adversely affected in recessions. The attractiveness of refinancing terms also depends on existence of multiple lenders competing to extend mortgage credit. As suggested by both extensive theoretical literature in industrial organization (e.g., Rotemberg and Saloner 1987) and by empirical studies of pricing in the banking sector (e.g., Hannan and Berger 1991, Neumark and Sharpe 1992), less competitive lenders respond more slowly to changes in openmarket interest rates. If mortgage markets become less competitive in recessions, lenders might be able to limit their pass through of lower input costs to borrowers, thereby stunting transmission of monetary policy actions.

This paper studies the effect of competition on mortgage rates during the Great Recession - a period associated with drastic reductions in market interest rates, but also with unprecedented erosion in home values and with stress in the mortgage lending sector. We do so through the lens of a large-scale refinancing policy program - Home Affordable Refinancing Program, or HARP. While this program removed many of the barriers of insufficient home equity and fluctuations in borrower credit scores, it simultaneously limited competition in the mortgage market. It did so primarily by shielding current lenders from much of the underwriting risk on newly refinanced loans, but refusing to extend this treatment to other lenders. As a result, HARP created deep asymmetries in costs of refinancing between the current lenders and their would-be competitors. This windfall of market power to a subset of lenders provides us with a unique opportunity to focus on the effect of competition. 
In particular, we exploit HARP eligibility cutoffs to formulate a regression discontinuity framework that sweeps away many of the confounding factors that influence mortgage interest rates. Borrowers just above the HARP eligibility cutoff (defined as loan-to-value (LTV) ratio of 80 percent) found it more difficult to shop around, as their current lender held a clear competitive advantage that limited availability of alternative offers. In contrast, borrowers below the threshold could search for a mortgage among a greater subset of lenders.

We find that limited competition did result in higher interest rates for observationally very similar borrowers. Borrowers just above the HARP eligibility threshold paid between 15 and 20 basis points more in interest on their newly refinanced loans. This translates into $\$ 1,600$ - $\$ 2,500$ in extra lender profits for a typical $\$ 200,000$ mortgage loan. Using 2012 HARP refinancing volumes of 80-105 LTV loans as a benchmark, we estimate that this feature of the program transferred between $\$ 1$ and $\$ 1.5$ billion in that year alone from borrowers to lenders that were granted a de facto sizable competitive advantage. It should be mentioned that the empirical design explicitly trades off ability to generalize findings over the entire range of refinanced mortgages in favor of being able to make strong causal inference claims in the vicinity of the eligibility threshold. That said, it is likely that the pricing power of existing lenders is only greater for high LTV (underwater) loans (Fuster et al. 2013) and that our findings represent a lower bound estimate of the anticompetitive effects of HARP.

Our analysis is aided by the ability to control for many observable factors that would typically affect interest rates and other contract terms and make interpretation of results difficult. Specifically, we use loan-level mortgage servicer dataset provided by Black Knight's Lender Processing Services (LPS) Applied Analytics (formerly McDash). This dataset contains borrower FICO score at time of origination, loan size, lien position, and occupancy status, as well as a full array of contract features including contract type (FRM/ARM), amortization schedule, existence of prepayment penalty, etc. Importantly for the identification of discontinuity, the dataset also contains LTV at origination - a measure that is based on the contemporaneous home value assessment and that is serves as the key determinant of HARP eligibility.

Our empirical design further relies on temporal variation in program structure and the resulting asymmetries in treatment of existing lenders and potential new lenders. We compare the 
behavior of interest rates around the eligibility threshold in three distinct policy regimes: prior to HARP (Jan 2005-Feb 2009) when lender treatment was symmetric; under the initial formulation of the program, the so-called HARP 1.0 (Mar 2009-Dec 2011), when existing lenders enjoyed some advantage; and under the revised program, the so-called HARP 2.0 (Jan 2012-Dec 2012), when the advantage received by existing lenders became greater.

This paper is closely related to several recent studies of mortgage market competitiveness and pass-through. Fuster et al. (2013) examine the reasons behind a spike in the spread between MBS rates directly influenced by the Federal Reserve quantitative easing purchases and mortgage rates available to borrowers throughout 2012 . They conclude that although industry capacity and rising costs of mortgage origination contributed to the increase in spreads, rising market concentration and lesser competitive pressures also played a role. Scharfstein and Sunderam (2014) take a longer perspective in relating market power of lenders to pass-through of policyinfluenced MBS prices to mortgage interest rates. The study exploits temporal and crosssectional fluctuations in mortgage industry concentration over the 1990-2011 period. They find that locations in which bank mergers raised the degree of lender concentration experienced a substantially smaller pass-through of lower market interest rates. In a contemporaneous paper, Agarwal et al. (2014) also examine the effect of HARP on mortgage interest rates. Unlike this paper, the authors pursue a different identification strategy and focus on gauging the impact of program design on loans over a wide range of LTV values.

Our paper is also related to a rapidly growing literature that examines the importance of institutional frictions in effective implementation of stabilization programs, particularly in housing markets. Some of the papers in this literature focus on agency frictions present in renegotiating securitized mortgage contracts (e.g., Piskorski, Seru, and Vig 2010, Agarwal et al. 2011) or contracts with multiple claimants (Lee, Mayer, and Tracy 2012, Bond et al. 2013, Agarwal et al. 2013a) Other papers focus on organizational structure of agents that intermediate policy actions, particularly mortgage servicers (Levitin and Twomey 2011, Agarwal et al. 2013b). Finally, this paper contributes to a literature that evaluates ability of monetary policy actions to influence real economy, whether through its effects on housing markets directly (Fuster and Willen 2013), household balance sheets and access to credit (Keys et al. 2014, Di Maggio, Kermani, and Ramcharan 2014), or consumption (Mian, Sufi, and Rao 2011). 
The rest of the paper is organized as follows. Section II provides background information on HARP and its evolution, and describes the empirical strategy. Section III details the data and provides key summary statistics. The following section presents regression discontinuity results, while section $\mathrm{V}$ discusses the robustness of these results to various specifications and data sample choices. Section VI discusses the results and concludes.

\section{Background and empirical strategy}

A. Developments in housing and mortgage markets in the wake of the subprime crisis

In the United States, mortgage contracts customarily contain a prepayment option that allows a borrower to pay off the balance of the loan at any time. ${ }^{1}$ When this payoff is funded by a new mortgage, a borrower effectively replaces an old obligation with a new one that carries a lower interest rate, carries a higher loan amount, or improves upon the original contract in some other way. Such refinancing transactions represent the easiest way for borrowers with fixed-rate mortgage to take advantage of declines in market interest rates. However, since the new mortgage needs to be underwritten, its availability depends critically on (i) the borrower remaining creditworthy (i.e., having a sufficiently high credit score, being able to provide evidence of income and/or assets, etc.), and (ii) the borrower being able to provide a sufficient downpayment, typically through borrowing no more than a certain percentage of the appraised home value.

Although historically the market for mortgage refinancing functioned smoothly, it encountered strong headwinds during the Great Recession. As home prices dropped precipitously, many households found themselves with little or no equity in their homes. ${ }^{2}$ The phenomenon of owing more on the house that it is worth came to be known as being "underwater". By one estimate, underwater households comprised $25 \%$ of all borrowers (12.1 million properties) by the first quarter of 2010 (CoreLogic, 2013).

\footnotetext{
${ }^{1}$ Some mortgage contracts have prepayment penalties that severely restrict ability to refinance during the first few years of the contract. Such contracts became more common during the expansion of the subprime lending markets, for which prepayment penalties can be shown to be an optimal contract feature (Mayer, Piskorski, and Tchistyi, 2013). We abstract from subprime markets and prepayment penalties in this paper.

${ }^{2}$ Home equity positions were further weakened by a common pre-crisis practice of equity extraction through cashout refinancings and home equity loans (Laufer 2013).
} 
The problem of insufficient equity was made worse by severe shocks to the private mortgage insurance (PMI) industry. Under normal market conditions, households that could not afford a 20 percent down payment were able to put in a smaller equity stake if they simultaneously took out a PMI contract covering the down payment shortfall. In the immediate aftermath of the crisis, the PMI industry was reeling from huge losses, with several prominent companies ceasing writing new policies altogether. Moreover, as PMI coverage is typically capped at 15 percent of home value, PMI was never going to be a solution for households with less than 5 percent of equity in their homes (LTV 95). In all, an estimated 30 percent of mortgage borrowers did not have sufficient equity to refinance their loans in the beginning of 2010 (CoreLogic, 2013).

Mounting job losses during the Great Recession put a further dent into household ability to refinance mortgages as lenders were unable to underwrite new loans in the absence of a documented stream of income. Income shocks associated with job loss put additional stress on household ability to service their existing debt obligations. When such shocks resulted in delayed payments or delinquencies, household credit scores took a hit, in some cases pushing them outside of the range considered to be necessary for mortgage loans.

Finally, refinancing was made more difficult by rapid consolidation in the mortgage industry. Private securitization markets shut down, as investors fled mortgage-backed securities that were not explicitly backed by the federal government. Banks exercised extreme caution in underwriting loans that they would keep on their balance sheet, as they were rebuilding their capital base. As an extreme example, mortgages on homes with little or negative equity would be considered unsecured credit, triggering prohibitive capital charges.

Mortgages backed by government-sponsored enterprises (GSEs), Fannie Mae and Freddie Mac, constituted the largest share of outstanding mortgage debt at the beginning of the Great Recession. After experiencing losses of nearly $\$ 15$ billion on these mortgages in the early stages of the housing crisis, GSEs were placed into conservatorship in September 2008 by their regulator, the Federal Housing Finance Agency (FHFA). Under the terms of the conservatorship, the GSEs received a capital infusion from the U.S. Treasury and their actions became subject to stringent oversight from FHFA, which was granted additional regulatory powers. The conservatorship agreement made explicit the support of the federal government for mortgage 
securities guaranteed by the GSEs. Consequently, GSE-backed loans increasingly became the primary conduit for mortgage lending, accounting for $63 \%$ of total flows in $2009 .^{3}$

\section{B. HARP description}

Against the backdrop of severe malfunctions in mortgage markets, the Obama Administration implemented the Financial Stability Plan in February of 2009, which included the Home Affordable Refinancing Program, or HARP. HARP was meant to enable households with insufficient equity to exercise their prepayment option and take advantage of lower interest rates through refinancing. To that end, the Administration worked with the Treasury Department and FHFA to get the GSEs to agree to provide credit guarantees on mortgages that they already backed, even in cases when such mortgages did not have enough equity, i.e. mortgages that had LTV higher than 80 percent.

Under HARP, if mortgages with LTV in excess of 80 percent had PMI at origination, the insurance companies would transfer it. If they did not have PMI, the borrowers were allowed not to get it as a prerequisite for receiving a credit guarantee from the GSEs. Given the credit guarantees from the federal government, private investors were willing to fund new loans. These proceeds went towards paying off the existing MBS investors, who then realized capital losses from surrendering high-interest paying assets in a low-interest-rate environment. On the other hand, borrowers that refinanced through HARP lowered their interest payments. Refinanced mortgages also represented a potentially substantial reduction in the net present value of their mortgage obligations (Eberly and Krishnamurthy 2014). Correspondingly, the twin goals of HARP were to provide economic stimulus to the extent that liquidity-constrained borrowers have higher marginal propensities to consume than MBS investors and to lower the likelihood of delinquencies and subsequent foreclosures that generate substantial deadweight losses (Campbell, Giglio, and Prathak 2010, Mian, Sufi, and Trebbi 2011).

Waiving the requirement for private insurance for mortgages with less than 20 percent equity required modifying the GSE charter, which FHFA in its role as the conservator could do. In order to not saddle the GSEs with any new credit risk, the FHFA only allowed HARP

\footnotetext{
${ }^{3}$ For comparison, 25\% of mortgages funded in 2009 received credit backing from other government agencies (FHA and VA), and only 12\% were funded without government guarantees (Urban Institute, 2014).
} 
refinancing for mortgages that had already been guaranteed by the GSEs. ${ }^{4}$ In other words, throughout the post-crisis period, ability to refinance low-equity or underwater mortgages remained limited to GSE-backed loans eligible for HARP.

The initial formulation of HARP (that became known as HARP 1.0) got off to a slow start. During the first full year of the program, only about 300,000 loans representing less than 10\% of the estimated set of eligible mortgages were refinanced. Market commentary pointed to a number of impactful deficiencies in program design. ${ }^{5}$ Those included frictions associated with resubordinating junior liens, porting existing PMI policies, and difficulties with packaging loans with LTV in excess of 105 percent. Perhaps most importantly, the program designed contained significant ambiguities about treatment of representations and warranties that curtailed lender willingness to participate in HARP.

In every mortgage transaction, the mortgage originator certifies that the information it collected as part of the origination process, such as borrower's income, assets, and house value, is truthful. This certification is known as representations and warranties (R\&W) and it obligates the originator to buy back any mortgage found to be in violation of its R\&W. Particularly in the aftermath of the subprime crisis, it became common practice for mortgage investors to conduct aggressive audits for possible R\&W violations for every defaulted loan. Any such violation could potentially result in the investor "putting back" the defaulted loan to its originator, who would then bear all of the credit losses. Consequently, mortgage originators that securitized their loans through GSEs regarded R\&W as a major liability.

A refinanced loan that is newly underwritten brings with itself a fresh set of reps and warranties. If this loan later defaults, its $R \& W$ could subject the lender to the risk of bearing all credit losses. Since in the case of low-equity and underwater loans targeted by HARP the risk of default was considered to be elevated, lender participation in HARP hinged on the program treatment of $\mathrm{R} \& \mathrm{~W}$.

\footnotetext{
${ }^{4}$ Another tool for mitigating credit risk and minimizing moral hazard was the restriction of HARP to borrowers that had remained current on their mortgages.

${ }^{5}$ Amherst Securities (August 23, 2010) and Moody’s Analytics () contain thorough summaries of HARP 1.0 and summarize frictions embedded in its design.
} 
Recognizing this, HARP 1.0 lessened underwriting requirements and the attendant R\&W on loans refinanced through the program. However, these requirements were lessened asymmetrically. Lenders that were already servicing mortgages that applied for a HARP refinancing faced a new, weaker form of R\&W requirements. ${ }^{6}$ In contrast, lenders that were refinancing mortgages that they did not already service had to face a stringent set of $\mathrm{R} \& \mathrm{~W}$ treatment. To put this differently, under HARP 1.0 the existing lenders enjoyed some relaxation of putback risk when refinancing mortgages through the program, but new lenders (the would-be competitors of the existing lenders) did not.

In November of 2012, the FHFA announced a series of changes meant to improve HARP. HARP 2.0 removed the LTV limits and capped surcharges on refinanced loans. Another key change was clarification of treatment for $\mathrm{R} \& \mathrm{~W}$ and further relaxation of underwriting requirements.

However, the improvements in reps and warranties treatment continued to be limited to samelender refinancings. Thus, HARP 2.0 only perpetuated the asymmetries in treatment, and further tilted the competitive field towards servicers/lenders handling the original loans.

\section{Fuzzy regression discontinuity framework}

The asymmetric treatment of new and existing lenders in refinancing low-equity loans through HARP leads to our key identifying assumption - crossing the HARP eligibility threshold results in a discontinuous jump in the likelihood of refinancing with the same servicer/lender. Such jump would be consistent with HARP favoring refinancing with existing lenders. This, in turn, limits competition which could lead to higher interest rates paid by HARP borrowers. Outside of HARP competition is greater, as new lenders are not as concerned about exposure to R\&W risk. Concurrently, we need to establish that no other observable characteristics - whether borrower credit score measures, loan sizes, or other contract features - experience systematic discontinues out the HARP threshold of LTV 80.

We should stress that there is no hard prohibition on new lenders refinancing loans under HARP. Rather, the program design strongly favors the existing lenders, and so we are evaluating the relative ease of competition on either side of the threshold.

\footnotetext{
${ }^{6}$ A mortgage originator that securitized their loans through GSE typically retained servicing rights on those mortgages. This meant that, in their role of mortgage servicer, they collected payments, advanced them to the MBS trustee, and engaged in a variety of loss mitigating actions when loans became delinquent. For the purposes of this paper, we treat the terms "servicer" and "lender" interchangeably.
} 
Unfortunately, mortgage servicer data do not identify lender identity, nor do they allowing linking mortgages over time. This severely limits our ability to directly establish the discontinuity in same-lender refinancing shares at LTV 80. Nevertheless, we carried out a merge of servicer data with public records data from Data Quick that typically contain the name of the lender. The results, shown in Figure 1, depict a clear jump in the likelihood of same-lender refinancings at LTV 80. At the first glance, the low levels of same-lender refinancings on either side of the HARP eligibility threshold appear inconsistent with market estimates. However, this derives primarily from poor data quality. ${ }^{7}$ In a contemporaneous study, Agarwal et al. (2014) make use of administrative data that records precise identities of the original servicer/lender and the servicer/lender of a refinanced loan. These data suggest that nearly 90 percent of HARPeligible loans are refinanced through the same lender, as compared with 60 percent of mortgages refinanced outside of HARP.

Although the LTV threshold for HARP remained unchanged, we are able to exploit temporal variation in the relative competitive advantage afforded to the existing servicers. A loan with $\mathrm{LTV} \leq 80$ does not need HARP, and although refinancing it requires new underwriting, the risks are the same for existing and new lenders. In contrast, the preferential treatment for same-lender refinancings of LTV $>80$ mortgages became stronger under the HARP 2.0 regime as compared to the original program specification.

\section{Data and summary statistics}

\section{A. Main data source}

Our analysis uses residential mortgage data from Black Knight Lender Processing Services Inc. (LPS) Applied Analytics (formerly McDash), which cover approximately two-thirds of the residential mortgage servicing market. In addition to providing information on the product type, lien type, property type, level of documentation, and owner occupancy as of origination, the LPS data include a monthly panel of current loan characteristics, mainly relating to delinquency and

\footnotetext{
${ }^{7}$ In particular, public records data capture the name of the mortgage originator. Many of the smaller originators, known as correspondent lenders, sell their loans to wholesale lenders who then securitize them and retain servicing rights. Hence, the public records data often contain the name of the correspondent but not the servicer and if the servicer ends up refinancing the original loan, the matched data will incorrectly indicate a new lender. Moreover, many of the original lenders went out of business during the Great Recession, further obscuring the identity of the servicer handling a mortgage prior to HARP.
} 
foreclosure status. Critically for our analysis, the data include the purpose of the loan (purchase or refinance), the monthly interest rate, and the identity of the investor in each month since origination. Since only GSE-backed loans are eligible for refinancing through HARP, we need to be certain to properly identify loan investor. This is made difficult by the fact that mortgages are frequently warehoused by their originator for a number of months before being transferred to the entity that pools mortgages, potentially provides a credit guarantee, and sells the pool to the eventual investors. However, we note that within the first four months following origination, $95 \%$ of loans no longer transition across investors. This figure rises to $99 \%$ after six months, at which point only about $10 \%$ of loans initially classified as being held in portfolio remain unsecuritized. For this reason, all our analysis is based on the investor reported as of six months after origination.

One limitation of the data is the absence of a borrower identifier that would allow us to link initial purchase loans to subsequent refinances. Having such an identifier would allow us to ascertain that refinanced loans replaced mortgages eligible for HARP in terms of their origination date and payment status. In the absence of this information, we rely on the assumption that in the post-crisis period, loans with LTV greater than 80 percent could only have been refinanced through HARP. ${ }^{8}$ Since LPS provides precise information on the loan-to-value ratio and other characteristics as of origination, this limitation does not significantly impact our analysis.

In all of our results, we restrict attention to 30-year fixed rate refinance mortgages as defined by the LPS loan product codes. Since LPS provides dynamic information on the interest rate for each month in which the loan is outstanding, we further exclude a small number of loans for which the interest rate is variable or missing during the first twelve months since origination. In order to avoid any potential for irregular pricing, all loans in the sample are conventional firstlien mortgages for single-family, owner-occupied properties. In addition, we remove jumbo loans, loans with a pre-payment penalty, loans to borrowers with non-standard FICO scores (below 300 or above 900), and loans that have been outstanding more than six months upon entering the dataset. Given that HARP eligibility is limited to GSE-guaranteed loans, and taking

\footnotetext{
${ }^{8}$ A stronger version of this assumption is that loans with LTV greater than 80 percent that also do not have private mortgage insurance could only have been refinanced through HARP. We address this on one of the robustness checks in Section V.
} 
into account that treatment regime for same and new lenders around the eligibility threshold differs across Freddie Mac and Fannie Mae, we limit the analysis to the more straightforward case of loans purchased by Fannie within six months following origination. ${ }^{9}$ We also conduct a separate analysis of privately securitized (PLS) mortgages, although our ability to draw conclusions about these loans is limited by the steep drop in volume after 2007.

Figure 2 displays loan volumes for mortgages guaranteed by Fannie, purchased by private investors, and held in portfolio. As in subsequent analysis, we present results separately for the three time periods relevant to our analysis: pre-HARP, from January 2005 to February 2009; HARP 1.0, from March 2009 to December 2011; and HARP 2.0, from January 2012 to April 2013. As seen in Figure 2A, Fannie average refinance volume declines over time for loans with LTV ratios of $90 \%$ and below, but the decline is smaller for loans in the $80-90 \%$ LTV range than in the $70-80 \%$ LTV range. For loans with LTV ratios above $90 \%$, annual refinance volume actually increases under both HARP regimes. In contrast, private refinance volume essentially disappears after 2007 across all values of LTV (Figure 2B). For loans kept in portfolio, refinance volume drops dramatically in the post-crisis period for loans with LTV ratios above $80 \%$, but declines only slightly for less leveraged loans (Figure $2 \mathrm{~B}$ ). This underscores the earlier point that HARP represented a unique refinancing opportunity limited to borrowers with GSEbacked low-equity loans.

The interest rate on Fannie-backed mortgages is affected by a variety of surcharges linked to contract type, loan features, borrower FICO score, LTV, etc. These surcharges can be paid upfront in the form of loan points, but they are typically rolled into the rate of the loan, especially in case of refinancing transactions. ${ }^{10}$ Although the restrictions on loan and property type described above eliminate most loan-level pricing adjustments from our sample, borrowers with FICO scores below 740 may face additional charges under the Fannie pricing schedule. For this reason, we further restrict the sample to borrowers with FICO scores between 740 and 900 .

As seen in Figure 3, more than half of Fannie refinances under HARP are made by borrowers with a FICO score of at least 740, across all levels of LTV. Cash out refinances may also be

\footnotetext{
${ }^{9}$ In contrast to Fannie Mae, Freddie Mac imposed a number of additional restrictions on non-HARP loans, including a cap on their combined LTV ratio.

${ }^{10}$ The complete list of surcharges, known as loan-level pricing adjustments (LLPA) is available at: https://www.fanniemae.com/content/pricing/llpa-matrix-refi-plus.pdf
} 
subject to pricing adjustments; however, as shown in Figure 2, cash out status is not provided for most loans in our sample. We will return to this issue in the robustness analysis.

\section{B. Summary statistics}

Summary statistics for Fannie-securitized loans with borrower FICO score between 740 and 900 are reported in Table 1. Since our research design relies on a discontinuity in the probability of refinancing with the same lender at a LTV ratio of $80 \%$, we restrict the regression sample to loans with an initial LTV ratio between $76 \%$ and $84 \%$. Loans with initial LTV ratios above $80 \%$ comprise about $8 \%$ of the total sample used in our analysis, with the percentage rising over our sample period. These loans are associated with somewhat lower home values and are more likely to carry full documentation than less leveraged loans, but mortgages on either side of the LTV cutoff are similar in terms of borrower FICO score and the likelihood of being located in a state that experienced particularly large declines in home prices (Arizona, California, Nevada, Florida, Michigan, or New Jersey). Although the average interest rate for loans with a LTV ratio above $80 \%$ is lower than the sample average, this largely reflects the skewness of high-LTV loan originations towards the latter part of the sample, when mortgage rates were lower. In contrast, the average spread between the mortgage interest rate and the concurrent Freddie average monthly 30-year FRM rate is somewhat higher for loans with LTV above $80 \%$, particularly under HARP 1.0 and HARP 2.0.

\section{Regression discontinuity results}

\section{A. Baseline results}

Figure 4 illustrates the crux of our identification strategy, which exploits the discontinuity in the likelihood for same-servicer refinances at a LTV ratio of $80 \%$. For Fannie-backed mortgages in each period (Panel A), we plot the mean difference between the mortgage interest rate and the reference survey rate within 0.1 percentage point LTV bins. ${ }^{11}$ Observing the spread, rather than the mortgage rate, as our primary outcome allows us to account for the substantial decline in the market interest rate over time when comparing loan pricing in different periods. In the pre-

\footnotetext{
${ }^{11}$ The reference rates are from the weekly Freddie Mac (FHLMC) surveys for the 30-year fixed-rate first-lien prime conventional conforming home purchase mortgages with a loan-to-value ratio of 80 percent. We use monthly averages of weekly surveys.
} 
HARP period, the spread appears to increase as LTV rises above the $80 \%$ threshold, although the average spread is quite noisy for loans in the 80 to $82 \%$ range of LTV. The discontinuity becomes more pronounced and increases in magnitude as HARP 1.0 and HARP 2.0 come into effect. In contrast, no discontinuity is apparent for private label mortgages in any period (Panel B of Figure 4), although the small sample size creates considerable noise.

Our primary analysis employs a framework similar to the nonparametric results in Figure 4, but introduces a regression discontinuity (RD) design in order to estimate the magnitude and precision of the interest rate jump in each time period. In theory our research question calls for a "fuzzy" RD design, since exceeding the $80 \%$ LTV threshold increases the probability of treatment (refinancing with the same servicer) by less than one. Since we are unable to observe the identity of the servicer, we implement a "sharp" RD design, which assumes that the increase in the probability of treatment is equal to one at the discontinuity. In practice, this assumption reduces the magnitude of our estimates relative to a "fuzzy" design, since the denominator of the Wald estimator is set to equal one.

The mechanics of the estimation are described by Nichols (2009). We fit local linear regressions on either side of the LTV cutoff using a triangular kernel, although in practice our results are not sensitive to kernel choice. The baseline results using optimal bandwidths are displayed in Figure 5. ${ }^{12}$ As in Figure 4, the estimated discontinuity is positive for Fannie-backed loans under HARP 1.0 and HARP 2.0. At a first glance, however, there also appears to be a large discontinuity in the pre-HARP period. Using a larger bandwidth, depicted in the bottom half of Figure 5, the preHARP discontinuity virtually disappears, so that the estimated discontinuity is positive and increasing over time.

Since these figures suggest that the RD estimates may be sensitive to bandwidth choice, we plot the discontinuity estimates and associated standard errors for a wide range of bandwidths (Figure 6), where the optimal bandwidth is denoted in red. While the estimated discontinuity under the optimal bandwidth is large and positive in the pre-HARP period, it is statistically insignificant

\footnotetext{
${ }^{12}$ The bandwidth determines the length of the LTV bin over which each local linear regression is estimated. Intuitively, a higher bandwidth produces a smoother fit, with very high bandwidths effectively imposing linear fits on either side of the discontinuity. The optimal bandwidth, which minimizes squared bias plus variance, is computed using the procedure described in Imbens and Kalyanaraman (2012). Other methods of optimal bandwidth selection, including cross-validation, are described in Lee and Lemieux (2010).
} 
and is not robust to either an increase or decrease in bandwidth size. In contrast to the large standard errors in the pre-HARP period, the estimates under HARP 1.0 and HARP 2.0 are much more precise, despite the smaller sample size. ${ }^{13}$ Under the optimal bandwidth, the HARP 2.0 estimate is positive and significant at the $1 \%$ level. Looking at the limiting estimates as bandwidth increases, the estimated discontinuity is small and significant in the pre-HARP period; larger and highly significant in the HARP 1.0 period; and larger and still more significant in the HARP 2.0 period (Table 2).

Another striking feature of the HARP 2.0 period is the upward shift in interest rates on either side of the LTV 80 threshold (Figures 5 and 6). During this period, the Federal Reserve engaged in large-scale purchases of agency MBS (i.e., MBS backed by Fannie Mae and Freddie Mac) which culminated in the September 2012 FOMC announcement of further increase in the size of its MBS purchases. These actions pushed mortgages rates to record lows and unleashed a wave of refinancings. However, multiple observers noted that the spread between the MBS yields and mortgage interest rates, which is strongly correlated with lender profitability, reached unprecedented highs during this period. A recent study by Fuster et al. (2013) attributed this phenomenon to capacity-constrained lenders rationing on price during a period of peak demand and exercising their pricing power. Our finding of the upward shift in rates is fully consistent with this explanation.

\section{B. Placebo test}

To verify that these interest rate discontinuities are due to preferential treatment of same-servicer refinances under HARP, we would like to compare the baseline results in Figure 5 to a set of loans that were not affected by HARP, namely privately-held mortgages. Figure 7 shows RD results for the sample of PLS loans refinanced during our sample period. In no period is the discontinuity in interest rate spread statistically significant, nor does the discontinuity appears to be increasing over time. Moreover, both the size and direction of the discontinuity are highly sensitive to bandwidth choice (not shown). At bandwidths below the optimum, the point estimates are positive, while at the optimal bandwidth the estimated discontinuity is negative in

\footnotetext{
${ }^{13}$ In all of the figures, confidence intervals and p-values are based on standard least squares robust standard errors. The significance level of the estimates does not change when we estimate bootstrapped standard errors (see Table 2).
} 
the HARP 1.0 and HARP 2.0 periods, and appears to approach zero as the bandwidth increases. The sensitivity of the results to bandwidth choice may be due to the precipitous drop in postcrisis loan volume, which results in large standard errors and limits the potential for any inference about private label loans. Still, the results for privately owned mortgages display no similarity to the discontinuities observed for HARP-eligible loans.

\section{Robustness of results to alternative specifications}

A. Local smoothness of key borrower and loan characteristics

The validity of the regression discontinuity design rests on the similarity of treated and untreated loans on either side of the threshold. One important corollary is the local smoothness of other variables that determine loan pricing in the vicinity of the cutoff. Although we account for many of these variables by imposing the sample restrictions outlined above, the necessity of maintaining a statistically meaningful sample size prevents us from restricting the sample along every variable that may affect the mortgage interest rate. To test whether the smoothness assumption holds, we repeat the RD analysis described above with borrower FICO score, home value, and level of documentation as the outcome variables. As seen in Figure 8, Panel A, the estimated discontinuity in FICO score at the cutoff is very small in magnitude and statistically insignificant at both the optimal bandwidth and larger bandwidths. These results suggest that the rising discontinuity in the interest rate spread for Fannie-owned mortgages is not due to a decline in credit quality over time. Panels B and C in Figure 8, however, show statistically significant discontinuities in appraisal amount and documentation for several time periods and bandwidths. In particular, the probability of a refinance loan being fully documented experiences a large jump at the $80 \%$ LTV threshold in the HARP 1.0 and HARP 2.0 periods. The coincidence of these discontinuities with the implementation of HARP could be explained by different definitions of full documentation between HARP and non-HARP loans, since HARP was designed to streamline documentation requirements. In addition, the discontinuities in home value in Panel $\mathrm{B}$ are not robust to bandwidth choice, nor do they change monotonically over time. Thus, although the lower two panels show some differences in loan characteristics on either side of the discontinuity, it is not obvious that these dissimilarities are driving the baseline results.

\section{B. Propensity-matched sample}


As an additional check, however, we attempt to account for differences in loan characteristics by performing a nearest neighbor propensity score match in each time period, with each loan above the LTV cutoff matched without replacement to a similar loan below the cutoff. The match criterion is the conditional treatment probability from a probit model, where the independent variables include a quadratic in FICO score, the log home value, state fixed effects, and indicators for full, low, and no documentation. Note that by construction, the matched sample will minimize differences on all observable characteristics on either side of the LTV 80 threshold. This is confirmed by summary statistics for the matched sample displayed in Table 3. Matched loans above and below 80\% LTV are very similar along all observable dimensions, with the exception of interest rate spread in the HARP 1.0 and HARP 2.0 periods.

As seen in Figure 9, the RD results for rate spread are even stronger in the matched sample, with the discontinuity diminishing in the pre-HARP period relative to the baseline results and increasing in magnitude under HARP 1.0 and HARP 2.0. RD estimation results for home value and full documentation status in the matched sample show a substantial attenuation relative to the full sample, though it does not disappear entirely. Although not all differences in loan characteristics are accounted for, the robustness of the rate spread estimates suggests that these differences are not driving our baseline results.

\section{Sensitivity to removing LTV 80 loans and loans with private mortgage insurance}

One loan characteristic which we are not able to evaluate, however, is whether borrowers took cash out at the time they refinanced their mortgage. Although LPS provides an indicator for refinancing transactions that include cash out, a substantial fraction of loans are categorized as "unknown cash out," particularly in the post-crisis period. Cash out refinances are problematic because they may necessitate loan-level pricing adjustments for mortgages refinanced under HARP.

Furthermore, by taking cash out, borrowers can also manipulate the assignment variable, thereby threatening the validity of the regression discontinuity design. For example, a borrower with a LTV ratio of $78.31 \%$ prior to refinancing could increase the loan amount up to the $80 \% \mathrm{LTV}$ threshold. Alternatively, borrowers could pay down their mortgage to push the initial LTV down to the $80 \%$ cutoff. In either case, a LTV ratio of exactly $80 \%$ at the time of refinancing may 
indicate borrower manipulation of the loan amount, violating the assumption that treatment is random in the vicinity of the cutoff. ${ }^{14}$

For this reason, we discard loans with an initial LTV ratio of exactly $80 \%$ and repeat the baseline $\mathrm{RD}$ estimation. In terms of magnitude and significance, the estimates shown in Figure 9 are similar to the baseline results in Figure 5. The main difference is the statistical significance of the pre-HARP discontinuity; at large bandwidths, however, the magnitude of the discontinuity in the pre-HARP period is substantially smaller than under HARP 1.0 or HARP 2.0.

Finally, we stress test our earlier assumption that loans with LTV $>80$ percent could only have been originated through HARP in the post-crisis period. To do this, we exclude all loans in our sample that indicate presence of PMI coverage. Although having PMI is not an indication of refinancing outside of HARP, not carrying PMI while having less than 20 percent equity is synonymous with a HARP refinancing. As shown in the bottom panel of Figure 9, this restriction preserves a strong discontinuity in interest rates at the HARP threshold, which increases under HARP 2.0.

\section{Conclusions}

This paper studies the effect of competition on mortgage rates through the lens of a large-scale refinancing policy program - Home Affordable Refinancing Program, or HARP. The program, introduced in the time of severe market stress during the Great Recession facilitated access to refinancing by borrowers whose home values were eroded by falling real estate prices. However, HARP simultaneously limited competition in the mortgage market by favoring lenders already servicing program-eligible loans. While other lenders could theoretically compete for HARP refinancings, they faced higher risk from exposure to representations and warranties they had to take on. This windfall of pricing power to a subset of lenders provides us with a unique opportunity to focus on the effect of competition.

\footnotetext{
${ }^{14}$ In the LPS data, loan-to-value ratio is reported to the nearest hundredth of a percentage point. However, there is a large clustering of values at $80 \%$, and to a lesser extent at other integer values of LTV. If borrowers do not pay down or cash out their mortgage prior to refinancing and servicers report exact values of the LTV ratio, then it is highly unlikely that a refinanced loan will have an initial LTV of $80 \%$. One possible explanation for the density at $80 \%$ is rounding by particular servicers to the nearest integer value of LTV before reporting to LPS. Since the data do not contain a servicer identifier, however, it is not possible to check whether this is the case.
} 
We do so by utilizing a fuzzy regression discontinuity design around the HARP eligibility threshold of loan-to-value ratio of 80 percent. We show a jump in mortgage interest rates precisely at this threshold, which is robust to numerous estimation choices and sample restrictions. Our results suggest that limiting competition raised interest rates on 30-year fixedrate mortgages by 15 to 20 basis points, translating into measurably higher lender profits.

HARP loans present potentially the most striking example of market power on the part of the large servicers that controlled most of HARP-eligible loans. Under the terms of the program, refinanced loans required little to no underwriting and were thus the cheapest to originate. By retaining the GSE guarantees, they continued to carry no credit risk and, in the case of samelender refinancing, they had extremely low putback risk. Their MBS pools traded at a substantial premium that reflected their low prepayment risk, since HARP loans cannot be refinanced again, per program rules. In a competitive environment, one would thus expect lenders to pass some of the resulting cost savings (whether from underwriting, lower putback risk, or lower interest costs) to the borrowers. However, as we show in this paper, precisely the opposite had occurred.

Our findings suggest that certain features in policy design can substantially influence the distribution of gains. While the anti-competitive features of HARP may appear to have curtailed borrower gains by relatively small amounts, they resulted in sizable increases in profitability for a subset of lenders. These results further highlight the importance of restoring full competitiveness to mortgage refinancing markets. 


\section{References}

Agarwal, Sumit, Gene Amromin, Itzhak Ben-David, Souphala Chomsisengphet, Douglas D. Evanoff, 2011, The Role of Securitization in Mortgage Renegotiation, Journal of Financial Economics, 102(3), 559-578.

Agarwal, Sumit, Gene Amromin, Itzhak Ben-David, Souphala Chomsisengphet, and Yan Zhang, 2013a, Second liens and the Holdup Problem in Mortgage Renegotiation, mimeo.

Agarwal, Sumit, Gene Amromin, Itzhak Ben-David, Souphala Chomsisengphet, Tomasz Piskorski, and Amit Seru, 2013b, Policy Intervention in Debt Renegotiation: Evidence from the Home Affordable Modification Program, Working Paper.

Bond, Philip, Sharon Garyn-Tal, Ronel Elul, and David Musto, 2012, Does Junior Inherit? Refinancing and the Blocking Power of Second Mortgages, Working Paper 13-3/R, Federal Reserve Bank of Philadelphia.

Campbell, John Y., Stefano Giglio, and Parag Pathak, 2011, Forced Sales and House Prices, forthcoming, American Economic Review 101, 2108-2131.

CoreLogic, 2013, Negative Equity Report, available at http://www.corelogic.com/research/negative-equity/corelogic-q4-2012-negative-equityreport.pdf

Eberly, Janice and Arvind Krishnamurthy, 2014, Efficient Credit Policies in a Housing Debt Crisis, Brookings Papers on Economic Activity

Fuster, Andreas, Laurie Goodman, David Lucca, Laurel Madar, Linsey Molloy, and Paul S. Willen, 2013, The Rising Gap between Primary and Secondary Mortgage Rates, Economic Policy Review, Federal Reserve Bank of New York

Fuster, Andreas and Paul S. Willen, 2013, Payment Size, Negative Equity and Mortgage Default, NBER Working Paper 19345

Haughwout, A., E. Okah, and J. Tracy, 2010, Second Chances: Subprime Mortgage Modification and Re-Default, NY FED working paper.

Imbens, Guido and Karthik Kalyanaraman, 2012, Optimal Bandwidth Choice for the Regression Discontinuity Estimator, Review of Economic Studies, pp 1-27.

Keys, Benjamin J., Tanmoy Mukherjee, Amit Seru, and Vikrant Vig, 2010, Did Securitization Lead to Lax Screening: Evidence from Subprime Loans, Quarterly Journal of Economics 125, 307-362.

Keys, Benjamin J., Amit Seru, and Vikrant Vig, 2011, Lender Screening and Role of Securitization: Evidence from Prime and Subprime Mortgage Markets, Review of Financial Studies, forthcoming.

Keys, Benjamin J., Tomasz Piskorski, Amit Seru, and Vincent Yao, 2014, Mortgage Rates, Household Balance Sheets, and the Real Economy, working paper.

Laufer, Steven, 2013, "Equity Extraction and Mortgage Default," Finance and Economics Discussion Series 2013-30. Board of Governors of the Federal Reserve. 
Lee, Donghoon, Christopher Mayer, and Joseph Tracy, 2012, A New Look at Second Liens, NBER Working Paper 18269.

Levitin, Adam and Tara Twomey, 2011, Mortgage Servicing, Yale Journal on Regulation 28, pp $1-90$.

Mayer, Christopher, Tomasz Piskorski, and Alexei Tchistyi, 2013, "The Inefficiency of Refinancing: Why Prepayment Penalties Are Good for Risky Borrowers." Journal of Financial Economics 107, no. 3: 694-714

Mayer, Christopher, Edward Morrison, Tomasz Piskorski, and Arpit Gupta, 2014, Mortgage Modification and Strategic Behavior: Evidence from a Legal Settlement with Countrywide, American Economic Review 104, no. 9: 2830-2857.

Mian, Atif, Amir Sufi, and Francesco Trebbi, 2011, Foreclosures, House Prices, and the Real Economy, University of Chicago, Working paper.

Mian, Atif, Kamalesh Rao, and Amir Sufi, 2011, Household Balance Sheets, Consumption, and the Economic Slump, working paper.

Piskorski, Tomasz, Amit Seru, and Vikrant Vig, 2010, Securitization and Distressed Loan Renegotiation: Evidence from the Subprime Mortgage Crisis, Journal of Financial Economics 97(3), 369-397.

Scharfstein, David S. and Adi Sunderam, 2014, Market Power in Mortgage Lending and the Transmission of Monetary Policy, working paper. 


\section{Table 1: Summary statistics for the full sample}

This table presents summary statistics for Fannie Mae-securitized loans with borrower FICO score between 740 and 900 in the LPS Applied Analytics dataset. The spread is defined as the difference between the observed mortgage rates and the FHMLC survey reference rate.

\begin{tabular}{|c|c|c|c|c|c|c|c|c|c|c|c|c|c|}
\hline \multirow[b]{2}{*}{ Period } & \multirow[b]{2}{*}{ Variable } & \multicolumn{4}{|c|}{ All loans } & \multicolumn{4}{|c|}{ Below LTV 80 threshold } & \multicolumn{4}{|c|}{ Above LTV 80 threshold } \\
\hline & & $\mathbf{N}$ & Median & Mean & SD & $\mathbf{N}$ & Median & Mean & SD & $\mathbf{N}$ & Median & Mean & SD \\
\hline \multirow[t]{11}{*}{ Pre-HARP } & Mortgage rate & 127382 & 6.00 & 5.97 & 0.62 & 122135 & 6.00 & 5.97 & 0.62 & 5247 & 6.00 & 6.02 & 0.62 \\
\hline & Spread to survey rate & 127382 & -0.04 & -0.01 & 0.36 & 122135 & -0.04 & -0.01 & 0.36 & 5247 & -0.01 & 0.03 & 0.39 \\
\hline & LTV ratio & 127382 & 79.99 & 79.26 & 1.38 & 122135 & 79.90 & 79.11 & 1.20 & 5247 & 82.80 & 82.67 & 0.92 \\
\hline & FICO score & 127382 & 768.00 & 769.60 & 19.42 & 122135 & 768.00 & 769.66 & 19.44 & 5247 & 766.00 & 768.26 & 18.84 \\
\hline & Home value & 127382 & 299.04 & 315.22 & 127.03 & 122135 & 301.08 & 317.00 & 127.19 & 5247 & 252.28 & 273.72 & 115.61 \\
\hline & Full documentation & 127382 & 1.00 & 0.51 & 0.50 & 122135 & 1.00 & 0.51 & 0.50 & 5247 & 1.00 & 0.51 & 0.50 \\
\hline & Low documentation & 127382 & 0.00 & 0.11 & 0.32 & 122135 & 0.00 & 0.11 & 0.32 & 5247 & 0.00 & 0.13 & 0.34 \\
\hline & No documentation & 127382 & 0.00 & 0.13 & 0.34 & 122135 & 0.00 & 0.13 & 0.34 & 5247 & 0.00 & 0.10 & 0.30 \\
\hline & Sand state, MI, or NJ & 127382 & 0.00 & 0.24 & 0.43 & 122135 & 0.00 & 0.24 & 0.43 & 5247 & 0.00 & 0.20 & 0.40 \\
\hline & $\mathrm{LTV}=80 \%$ & 127382 & 0.00 & 0.46 & 0.50 & 122135 & 0.00 & 0.48 & 0.50 & 5247 & 0.00 & 0.00 & 0.00 \\
\hline & LTV $>80 \%$ & 127382 & 0.00 & 0.04 & 0.20 & 122135 & 0.00 & 0.00 & 0.00 & 5247 & 1.00 & 1.00 & 0.00 \\
\hline \multirow[t]{11}{*}{ HARP 1.0} & Mortgage rate & 120822 & 4.88 & 4.76 & 0.37 & 108309 & 4.88 & 4.75 & 0.37 & 12513 & 4.88 & 4.84 & 0.37 \\
\hline & Spread to survey rate & 120822 & 0.02 & 0.00 & 0.37 & 108309 & 0.02 & -0.01 & 0.36 & 12513 & 0.12 & 0.09 & 0.39 \\
\hline & LTV ratio & 120822 & 80.00 & 79.36 & 1.57 & 108309 & 79.77 & 79.03 & 1.24 & 12513 & 82.38 & 82.28 & 1.11 \\
\hline & FICO score & 120822 & 777.00 & 776.87 & 20.49 & 108309 & 777.00 & 776.93 & 20.47 & 12513 & 776.00 & 776.31 & 20.67 \\
\hline & Home value & 120822 & 286.16 & 303.67 & 125.58 & 108309 & 287.04 & 304.67 & 126.32 & 12513 & 281.12 & 294.94 & 118.72 \\
\hline & Full documentation & 120822 & 1.00 & 0.60 & 0.49 & 108309 & 1.00 & 0.58 & 0.49 & 12513 & 1.00 & 0.80 & 0.40 \\
\hline & Low documentation & 120822 & 0.00 & 0.07 & 0.26 & 108309 & 0.00 & 0.08 & 0.26 & 12513 & 0.00 & 0.03 & 0.18 \\
\hline & No documentation & 120822 & 0.00 & 0.13 & 0.33 & 108309 & 0.00 & 0.13 & 0.34 & 12513 & 0.00 & 0.10 & 0.29 \\
\hline & Sand state, $\mathrm{MI}$, or NJ & 120822 & 0.00 & 0.23 & 0.42 & 108309 & 0.00 & 0.22 & 0.42 & 12513 & 0.00 & 0.25 & 0.44 \\
\hline & LTV $=80 \%$ & 120822 & 0.00 & 0.41 & 0.49 & 108309 & 0.00 & 0.46 & 0.50 & 12513 & 0.00 & 0.00 & 0.00 \\
\hline & LTV $>80 \%$ & 120822 & 0.00 & 0.10 & 0.30 & 108309 & 0.00 & 0.00 & 0.00 & 12513 & 1.00 & 1.00 & 0.00 \\
\hline \multirow[t]{11}{*}{ HARP 2.0} & Mortgage rate & 31964 & 3.88 & 3.88 & 0.33 & 27340 & 3.88 & 3.86 & 0.33 & 4624 & 3.99 & 3.99 & 0.36 \\
\hline & Spread to survey rate & 29969 & 0.22 & 0.25 & 0.27 & 25659 & 0.20 & 0.23 & 0.26 & 4310 & 0.36 & 0.39 & 0.29 \\
\hline & LTV ratio & 31964 & 80.00 & 79.45 & 1.69 & 27340 & 79.68 & 78.98 & 1.26 & 4624 & 82.36 & 82.25 & 1.13 \\
\hline & FICO score & 31964 & 780.00 & 779.07 & 21.17 & 27340 & 780.00 & 779.14 & 21.15 & 4624 & 779.00 & 778.68 & 21.27 \\
\hline & Home value & 23795 & 279.58 & 291.74 & 123.06 & 20550 & 287.74 & 298.03 & 123.50 & 3245 & 229.90 & 251.91 & 112.32 \\
\hline & Full documentation & 31964 & 1.00 & 0.50 & 0.50 & 27340 & 0.00 & 0.49 & 0.50 & 4624 & 1.00 & 0.60 & 0.49 \\
\hline & Low documentation & 31964 & 0.00 & 0.00 & 0.02 & 27340 & 0.00 & 0.00 & 0.02 & 4624 & 0.00 & 0.00 & 0.00 \\
\hline & No documentation & 31964 & 0.00 & 0.09 & 0.28 & 27340 & 0.00 & 0.09 & 0.29 & 4624 & 0.00 & 0.06 & 0.23 \\
\hline & Sand state, MI, or NJ & 31964 & 0.00 & 0.32 & 0.46 & 27340 & 0.00 & 0.31 & 0.46 & 4624 & 0.00 & 0.33 & 0.47 \\
\hline & LTV $=80 \%$ & 31964 & 0.00 & 0.38 & 0.49 & 27340 & 0.00 & 0.45 & 0.50 & 4624 & 0.00 & 0.00 & 0.00 \\
\hline & LTV $>80 \%$ & 31964 & 0.00 & 0.14 & 0.35 & 27340 & 0.00 & 0.00 & 0.00 & 4624 & 1.00 & 1.00 & 0.00 \\
\hline \multirow[t]{11}{*}{ 2005-2012 } & Mortgage rate & 280168 & 5.00 & 5.21 & 0.89 & 257784 & 5.00 & 5.23 & 0.89 & 22384 & 4.88 & 4.94 & 0.81 \\
\hline & Spread to survey rate & 278173 & 0.03 & 0.02 & 0.36 & 256103 & 0.02 & 0.01 & 0.36 & 22070 & 0.15 & 0.13 & 0.39 \\
\hline & LTV ratio & 280168 & 80.00 & 79.33 & 1.51 & 257784 & 79.83 & 79.06 & 1.22 & 22384 & 82.50 & 82.36 & 1.09 \\
\hline & FICO score & 280168 & 773.00 & 773.82 & 20.47 & 257784 & 773.00 & 773.72 & 20.44 & 22384 & 774.00 & 774.91 & 20.73 \\
\hline & Home value & 271999 & 291.87 & 308.03 & 126.27 & 250994 & 293.94 & 310.13 & 126.70 & 21005 & 265.73 & 282.99 & 118.06 \\
\hline & Full documentation & 280168 & 1.00 & 0.55 & 0.50 & 257784 & 1.00 & 0.54 & 0.50 & 22384 & 1.00 & 0.69 & 0.46 \\
\hline & Low documentation & 280168 & 0.00 & 0.08 & 0.28 & 257784 & 0.00 & 0.09 & 0.28 & 22384 & 0.00 & 0.05 & 0.22 \\
\hline & No documentation & 280168 & 0.00 & 0.12 & 0.33 & 257784 & 0.00 & 0.13 & 0.33 & 22384 & 0.00 & 0.09 & 0.29 \\
\hline & Sand state, MI, or NJ & 280168 & 0.00 & 0.24 & 0.43 & 257784 & 0.00 & 0.24 & 0.43 & 22384 & 0.00 & 0.26 & 0.44 \\
\hline & $\mathrm{LTV}=80 \%$ & 280168 & 0.00 & 0.43 & 0.49 & 257784 & 0.00 & 0.47 & 0.50 & 22384 & 0.00 & 0.00 & 0.00 \\
\hline & LTV $>80 \%$ & 280168 & 0.00 & 0.08 & 0.27 & 257784 & 0.00 & 0.00 & 0.00 & 22384 & 1.00 & 1.00 & 0.00 \\
\hline
\end{tabular}




\section{Table 2: Baseline RD results in tabular form}

These tables show the results of fitting local linear regressions shown graphically in Figure 5. The top panel shows the estimates with least squares robust standard errors. The lower panel shows the estimates with bootstrapped standard errors.

\section{$\underline{\text { Robust standard errors }}$}

Spread of mortgage rate to FHMLC survey rate
Pre-HARP
HARP 1.0
HARP 2.0

(1)

(2)

(3)

\begin{tabular}{lccc}
\hline & & & \\
Optimal bandwidth & 0.193 & 0.0645 & $0.142^{* * *}$ \\
& $(0.129)$ & $(0.0346)$ & $(0.0384)$ \\
Large bandwidth (4) & $0.0493^{* *}$ & $0.113^{* * *}$ & $0.205^{* * *}$ \\
& $(0.0191)$ & $(0.00916)$ & $(0.0108)$ \\
$\mathrm{N}$ & 127382 & 120822 & 29969 \\
$\mathrm{~N}(80 \%$ or below) & 122135 & 108309 & 25659 \\
$\mathrm{~N}($ above $80 \%)$ & 5247 & 12513 & 4310 \\
\hline
\end{tabular}

\section{Bootstrapped standard errors}

Spread of mortgage rate to FHMLC survey rate

Pre-HARP HARP 1.0 HARP 2.0

(1)

(2)

(3)

\begin{tabular}{lccc} 
Optimal bandwidth & 0.193 & 0.0645 & $0.142^{* * *}$ \\
& $(0.141)$ & $(0.0358)$ & $(0.0355)$ \\
Large bandwidth (4) & $0.0493 * *$ & $0.113^{* * *}$ & $0.205^{* * *}$ \\
& $(0.0191)$ & $(0.00942)$ & $(0.0122)$ \\
$\mathrm{N}$ & 127382 & 120822 & 29969 \\
$\mathrm{~N}(80 \%$ or below) & 122135 & 108309 & 25659 \\
$\mathrm{~N}($ above $80 \%)$ & 5247 & 12513 & 4310 \\
\hline
\end{tabular}




\section{Table 3: Summary statistics for the matched sample}

This table presents summary statistics for the matched sample of Fannie Mae-securitized loans. Each of the loans in the treatment group (LTV > 80) is propensity-matched with another loan from the control group (LTV $\leq 80)$ on the basis of a quadratic in FICO score, the log home value, state fixed effects, and indicators for full, low, and no documentation loans.

\begin{tabular}{|c|c|c|c|c|c|c|c|c|c|}
\hline \multirow[b]{2}{*}{ Period } & \multirow[b]{2}{*}{ Variable } & \multicolumn{4}{|c|}{ Below LTV 80 threshold } & \multicolumn{4}{|c|}{ Above LTV 80 threshold } \\
\hline & & $\mathbf{N}$ & Median & Mean & SD & $\mathbf{N}$ & Median & Mean & SD \\
\hline \multirow[t]{10}{*}{ Pre-HARP } & Mortgage rate & 5247 & 6.00 & 6.01 & 0.61 & 5247 & 6.00 & 6.02 & 0.62 \\
\hline & Spread to survey rate & 5247 & -0.01 & 0.01 & 0.36 & 5247 & -0.01 & 0.03 & 0.39 \\
\hline & LTV ratio & 5247 & 79.93 & 79.12 & 1.20 & 5247 & 82.80 & 82.67 & 0.92 \\
\hline & FICO score & 5247 & 766.00 & 768.40 & 18.80 & 5247 & 766.00 & 768.26 & 18.84 \\
\hline & Home value & 5247 & 253.76 & 273.94 & 118.60 & 5247 & 252.28 & 273.72 & 115.61 \\
\hline & Full documentation & 5247 & 1.00 & 0.51 & 0.50 & 5247 & 1.00 & 0.51 & 0.50 \\
\hline & Low documentation & 5247 & 0.00 & 0.13 & 0.34 & 5247 & 0.00 & 0.13 & 0.34 \\
\hline & No documentation & 5247 & 0.00 & 0.10 & 0.30 & 5247 & 0.00 & 0.10 & 0.30 \\
\hline & SAND state & 5247 & 0.00 & 0.20 & 0.40 & 5247 & 0.00 & 0.20 & 0.40 \\
\hline & $\mathrm{LTV}=80 \%$ & 5247 & 0.00 & 0.49 & 0.50 & 5247 & 0.00 & 0.00 & 0.00 \\
\hline \multirow[t]{10}{*}{ HARP 1.0} & Mortgage rate & 12513 & 4.88 & 4.77 & 0.37 & 12513 & 4.88 & 4.84 & 0.37 \\
\hline & Spread to survey rate & 12513 & 0.02 & -0.01 & 0.37 & 12513 & 0.12 & 0.09 & 0.39 \\
\hline & LTV ratio & 12513 & 79.63 & 78.97 & 1.25 & 12513 & 82.38 & 82.28 & 1.11 \\
\hline & FICO score & 12513 & 776.00 & 776.22 & 20.61 & 12513 & 776.00 & 776.31 & 20.67 \\
\hline & Home value & 12513 & 279.57 & 298.64 & 126.97 & 12513 & 281.12 & 294.94 & 118.72 \\
\hline & Full documentation & 12513 & 1.00 & 0.80 & 0.40 & 12513 & 1.00 & 0.80 & 0.40 \\
\hline & Low documentation & 12513 & 0.00 & 0.03 & 0.17 & 12513 & 0.00 & 0.03 & 0.18 \\
\hline & No documentation & 12513 & 0.00 & 0.09 & 0.29 & 12513 & 0.00 & 0.10 & 0.29 \\
\hline & SAND state & 12513 & 0.00 & 0.25 & 0.43 & 12513 & 0.00 & 0.25 & 0.44 \\
\hline & $\mathrm{LTV}=80 \%$ & 12513 & 0.00 & 0.43 & 0.50 & 12513 & 0.00 & 0.00 & 0.00 \\
\hline \multirow[t]{10}{*}{ HARP 2.0} & Mortgage rate & 3245 & 3.99 & 3.94 & 0.34 & 3245 & 4.13 & 4.09 & 0.35 \\
\hline & Spread to survey rate & 3245 & 0.24 & 0.28 & 0.28 & 3245 & 0.45 & 0.44 & 0.29 \\
\hline & LTV ratio & 3245 & 79.62 & 78.98 & 1.24 & 3245 & 82.33 & 82.24 & 1.12 \\
\hline & FICO score & 3245 & 780.00 & 779.18 & 21.46 & 3245 & 780.00 & 779.07 & 21.23 \\
\hline & Home value & 3245 & 230.48 & 255.54 & 119.89 & 3245 & 229.90 & 251.91 & 112.32 \\
\hline & Full documentation & 3245 & 1.00 & 0.59 & 0.49 & 3245 & 1.00 & 0.59 & 0.49 \\
\hline & Low documentation & 3245 & 0.00 & 0.00 & 0.00 & 3245 & 0.00 & 0.00 & 0.00 \\
\hline & No documentation & 3245 & 0.00 & 0.05 & 0.22 & 3245 & 0.00 & 0.06 & 0.23 \\
\hline & SAND state & 3245 & 0.00 & 0.33 & 0.47 & 3245 & 0.00 & 0.32 & 0.47 \\
\hline & $\mathrm{LTV}=80 \%$ & 3245 & 0.00 & 0.43 & 0.50 & 3245 & 0.00 & 0.00 & 0.00 \\
\hline \multirow[t]{10}{*}{ 2005-2012 } & Mortgage rate & 21005 & 4.88 & 4.95 & 0.80 & 21005 & 4.88 & 5.02 & 0.78 \\
\hline & Spread to survey rate & 21005 & 0.06 & 0.04 & 0.37 & 21005 & 0.14 & 0.13 & 0.40 \\
\hline & LTV ratio & 21005 & 79.71 & 79.01 & 1.24 & 21005 & 82.50 & 82.37 & 1.08 \\
\hline & FICO score & 21005 & 774.00 & 774.73 & 20.66 & 21005 & 774.00 & 774.73 & 20.68 \\
\hline & Home value & 21005 & 265.57 & 285.81 & 124.94 & 21005 & 265.73 & 282.99 & 118.06 \\
\hline & Full documentation & 21005 & 1.00 & 0.69 & 0.46 & 21005 & 1.00 & 0.69 & 0.46 \\
\hline & Low documentation & 21005 & 0.00 & 0.05 & 0.22 & 21005 & 0.00 & 0.05 & 0.22 \\
\hline & No documentation & 21005 & 0.00 & 0.09 & 0.28 & 21005 & 0.00 & 0.09 & 0.29 \\
\hline & SAND state & 21005 & 0.00 & 0.25 & 0.43 & 21005 & 0.00 & 0.25 & 0.43 \\
\hline & $\mathrm{LTV}=80 \%$ & 21005 & 0.00 & 0.45 & 0.50 & 21005 & 0.00 & 0.00 & 0.00 \\
\hline
\end{tabular}


Figure 1: Share of loans refinanced with the same lender

The figure shows the share of loans estimated to have been refinanced with the same lender, as determined from matching of mortgage servicer observations with the public records database.

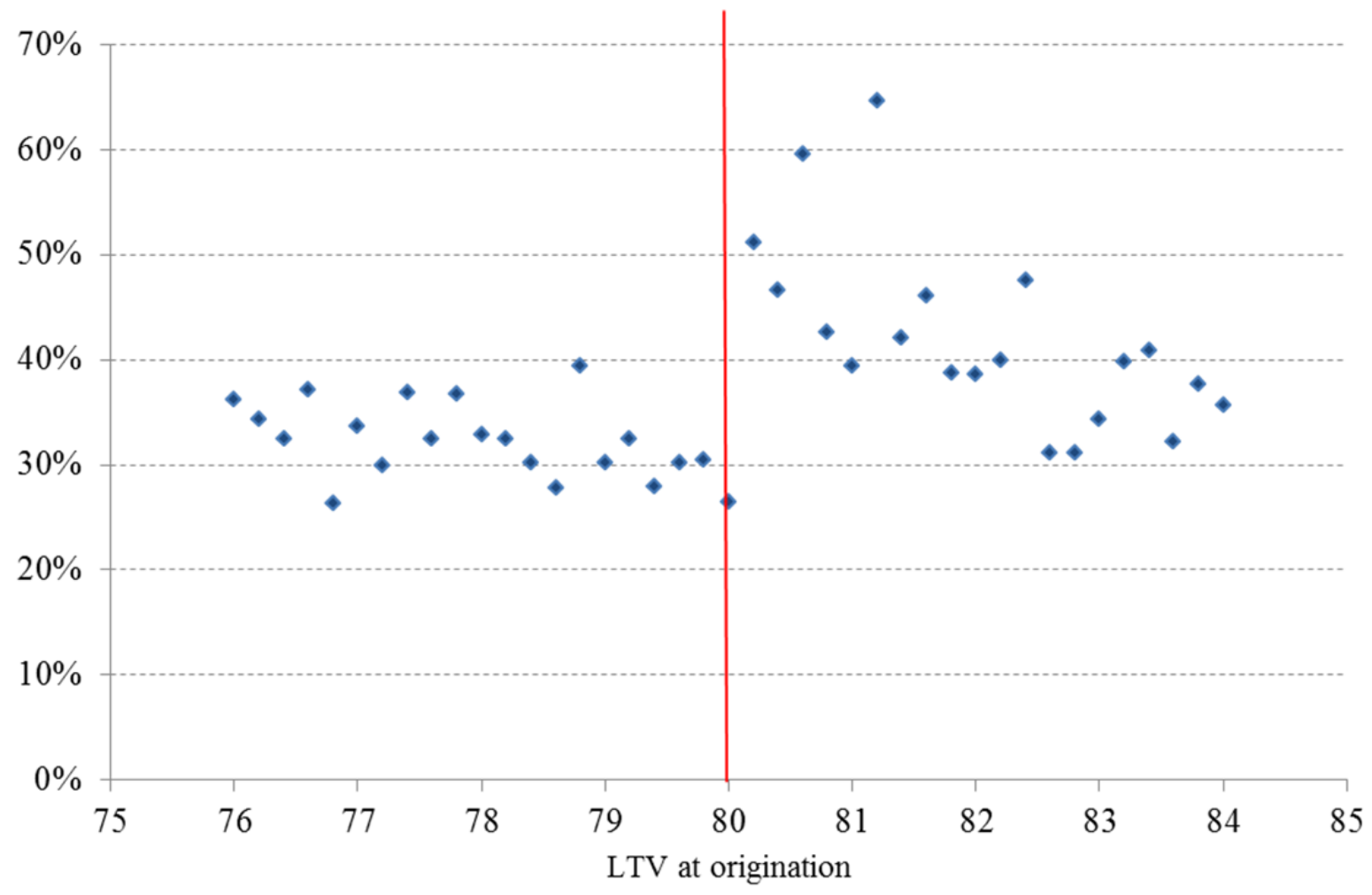




\section{Figure 2A: Fannie Mae refinancing volumes over time, by loan-to-value ratio}

The figure depicts refinancing volumes by Fannie Mae, broken out over three distinct periods: pre-HARP (January 2005- February 2009), HARP 1.0 (March 2009 - December 2011), and HARP 2.0 (January 2012 to April 2013). For each of the periods, refinanced loans are broken out by the loan-to-value ratio of the first-lien loan being refinanced. Mortgages with LTV $\leq 80$ do not require mortgage insurance and can be refinanced without HARP. Within each of the LTV groups, mortgages are categorized as those that increased the balance, returning some of it to the borrower in the form of cash, those that had no cash out, and those whose cash out status was not recorded by the servicer.

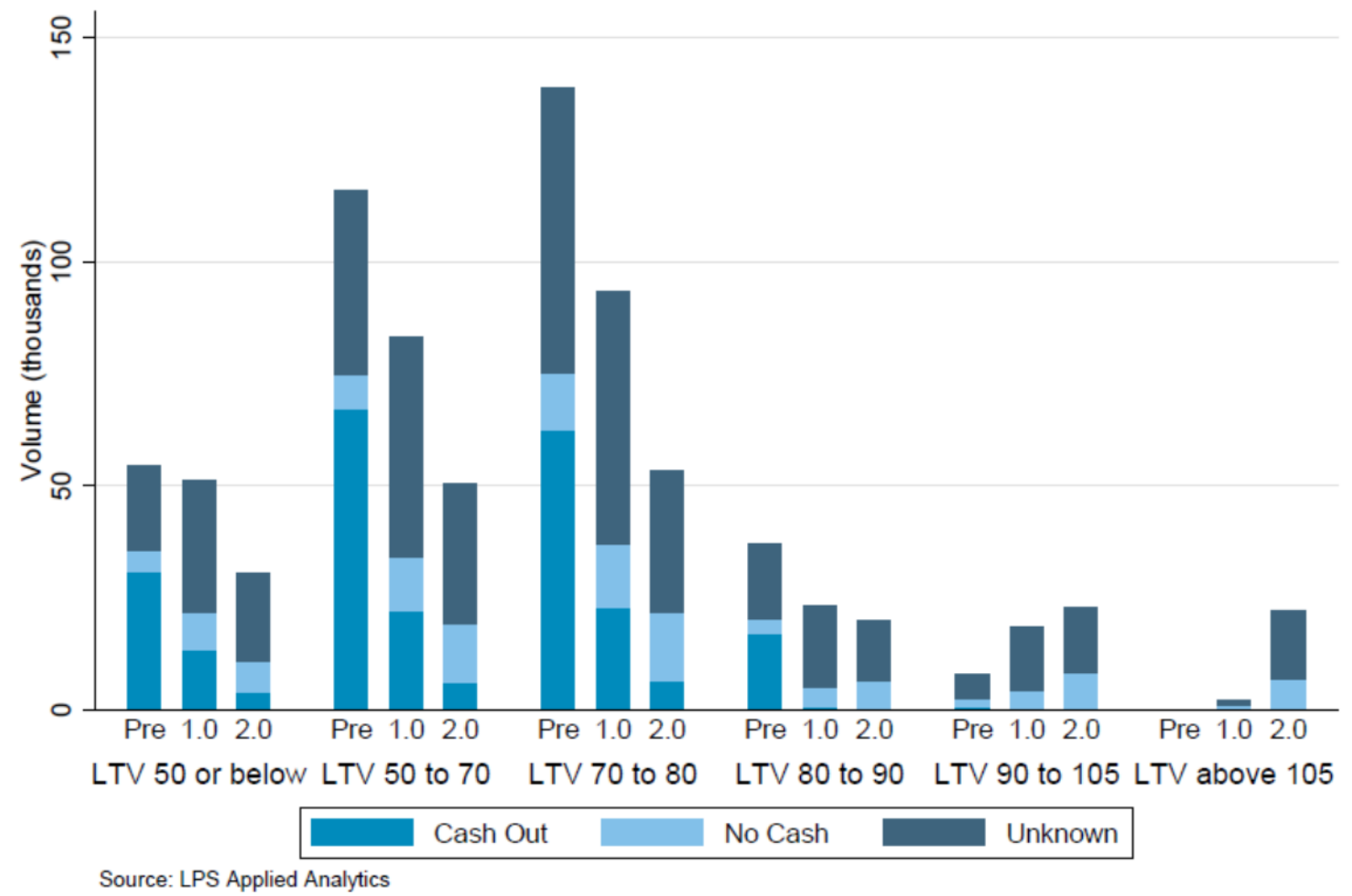




\section{Figure 2B: PLS and portfolio refinancing volumes over time, by loan-to-value ratio}

The figure depicts refinancing volumes in private label securitizations (PLS) or in bank portfolios, broken out over three distinct periods: pre-HARP (January 2005- February 2009), HARP 1.0 (March 2009 - December 2011), and HARP 2.0 (January 2012 to April 2013). For each of the periods, refinanced loans are broken out by the loan-tovalue ratio of the first-lien loan being refinanced. Mortgages with $\mathrm{LTV} \leq 80$ do not require mortgage insurance and can be refinanced without HARP. Within each of the LTV groups, mortgages are categorized as those that increased the balance, returning some of it to the borrower in the form of cash, those that had no cash out, and those whose cash out status was not recorded by the servicer.
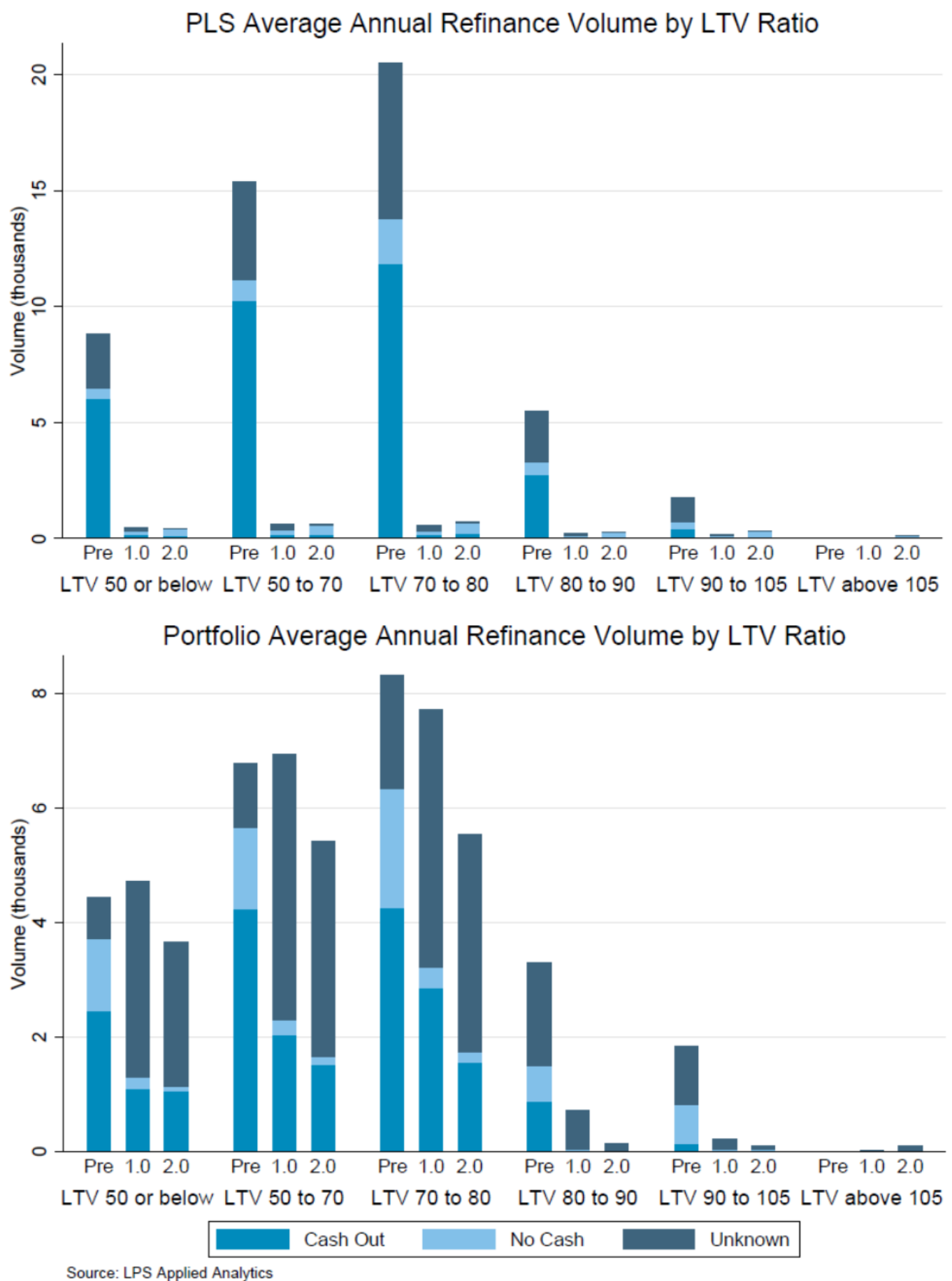


\section{Figure 3: Creditworthiness of Fannie mortgage refinancings over time, by loan-to-value}

ratio

The figure depicts refinancing volumes by Fannie Mae, broken out over three distinct periods: pre-HARP (January 2005- February 2009), HARP 1.0 (March 2009 - December 2011), and HARP 2.0 (January 2012 to April 2013).

Each of the volume bars is further partitioned into refinancings for borrowers with FICO scores above 740 for whom there are no additional loan surcharges, and those with scores below 740 .

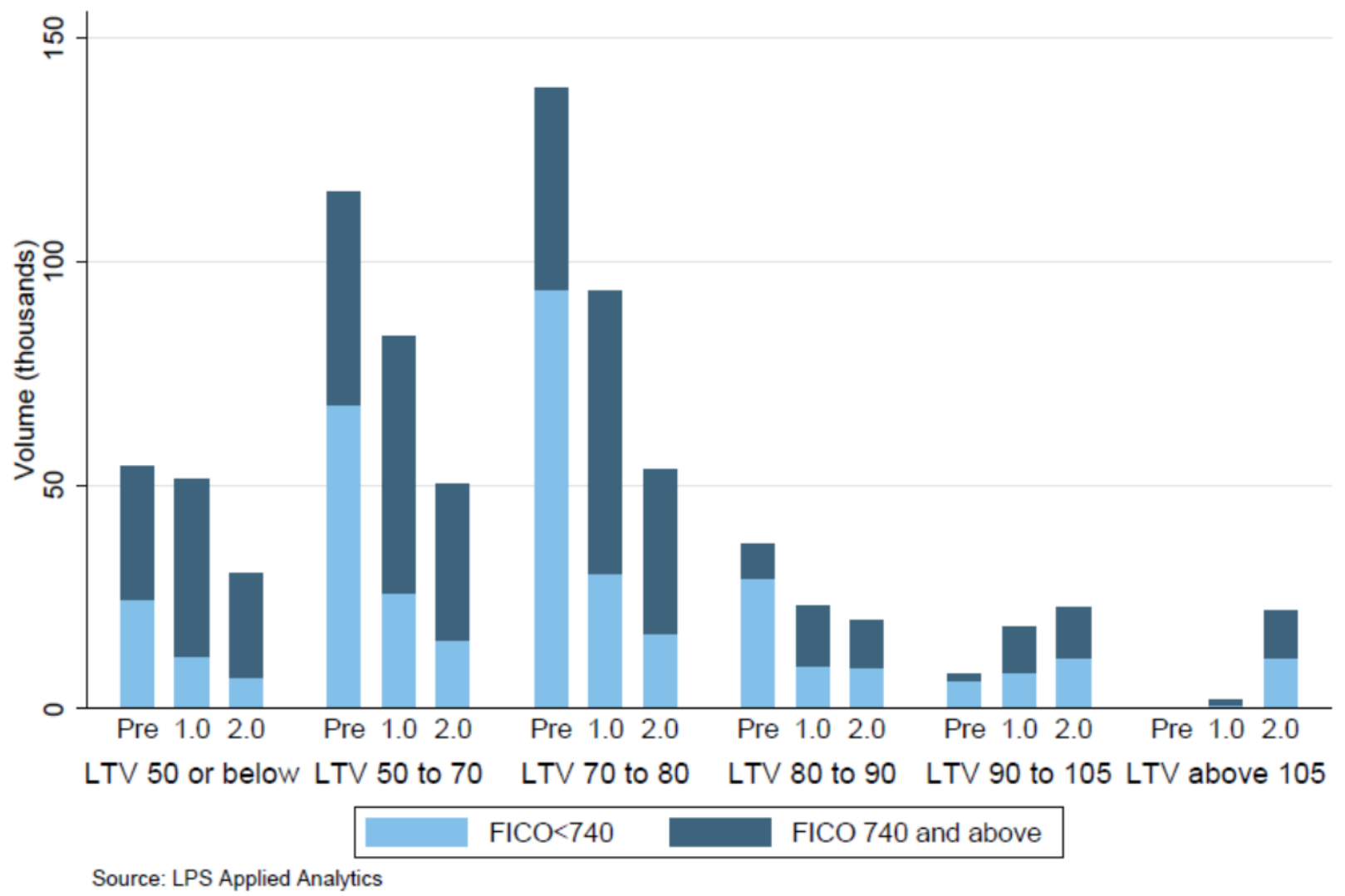




\section{Figure 4: Interest rates on refinanced mortgages around the HARP threshold}

The figure depicts raw data on mortgage interest rates for Fannie Mae refinancings (Panel A) and PLS refinancings (Panel B). Mortgage rates are presented as the contract loan rate on the 30-year fixed rate mortgage less the reference rate on a similar contract collected by FHMLC. Each dot represents the average rate for loans in the LTV bin of width 0.1 (e.g., loans with LTV between 79.0 and 79.1). The red line represents the HARP eligibility threshold of LTV 80. The three policy regimes are: pre-HARP (January 2005- February 2009), HARP 1.0 (March 2009 - December 2011), and HARP 2.0 (January 2012 to December 2012). The sample is limited to 30-year firstlien conventional FRM loans, with no prepayment penalties, collateralized by single-family owner-occupied properties, and originated for borrowers with FICO scores above 740.

\section{Panel A. Fannie Mae refinancings}

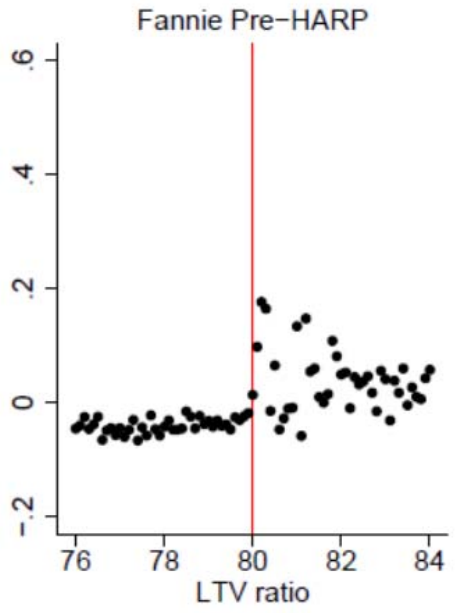

127382 observations

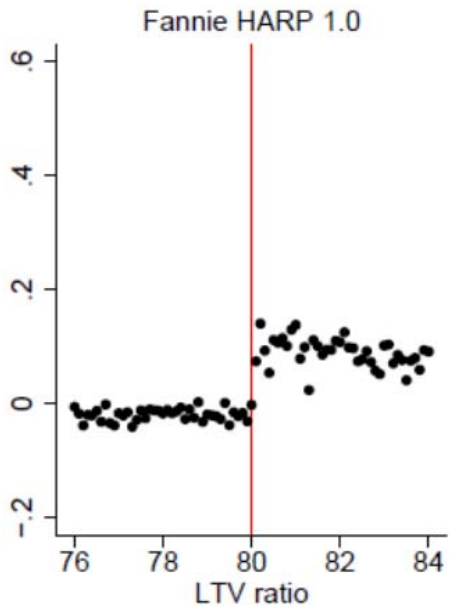

120822 observations

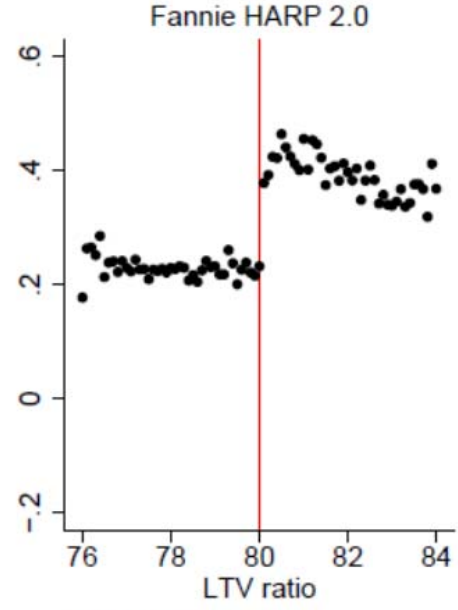

31964 observations

Source: LPS Applied Analytics

\section{Panel B. PLS refinancings}

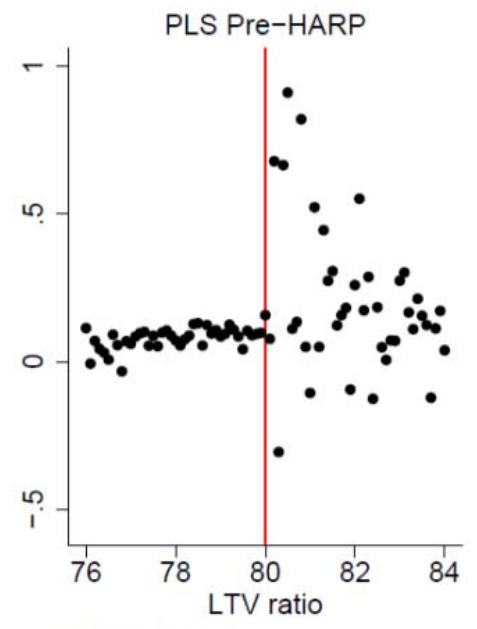

12528 observations

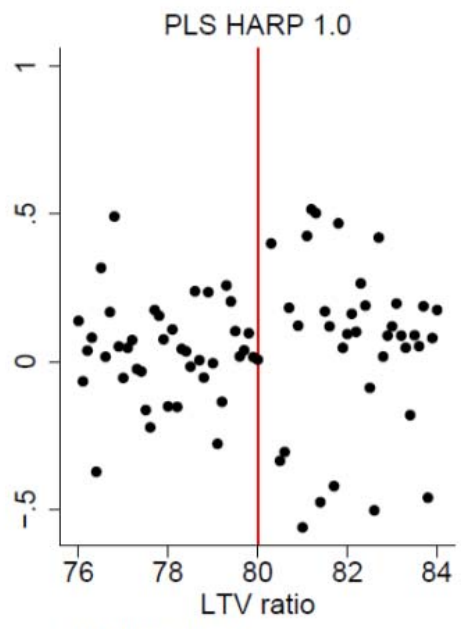

827 observations

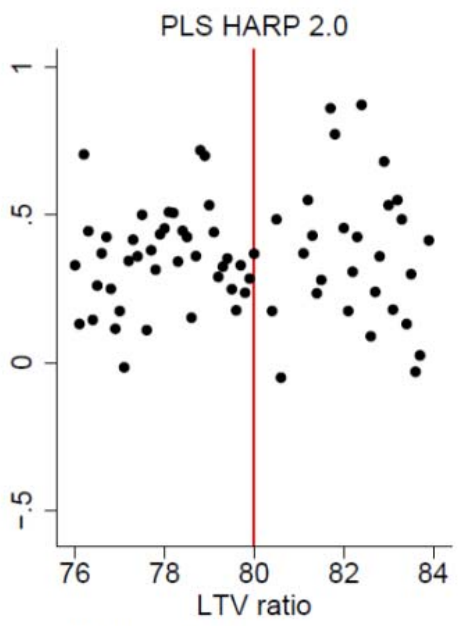

477 observations 


\section{Figure 5: Regression discontinuity in mortgage rates, Fannie Mae loans}

The figure shows the results of fitting local linear regressions on either side of the LTV cutoff using a triangular kernel in each of the three regimes, defined as before. The horizontal axis is expressed as deviations of LTV ratio from the HARP eligibility threshold of 80 . The vertical axis is expressed as the spread between the observed mortgage rates and the FHMLC survey reference rate. The top panel shows the results for the optimal bandwidth choice as described in Imbens and Kalyanaraman (2012). The bottom panel shows the results for the bandwidth that is 5 times the optimal. The sample is limited to 30-year first-lien conventional FRM loans, with no prepayment penalties, collateralized by single-family owner-occupied properties, for borrowers with FICO scores above 740 .
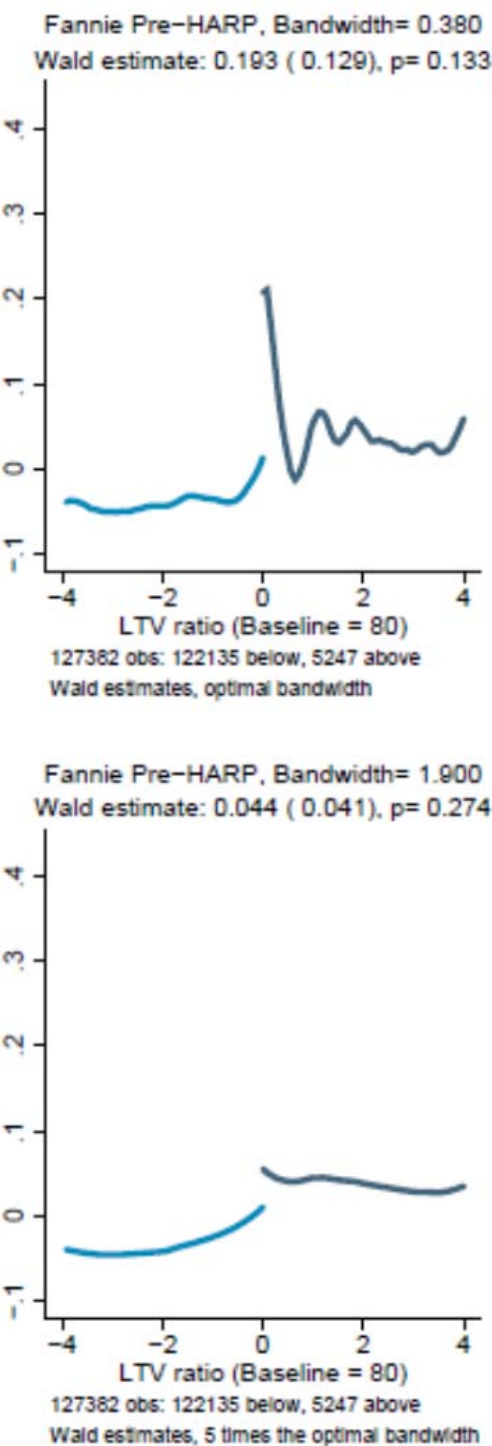

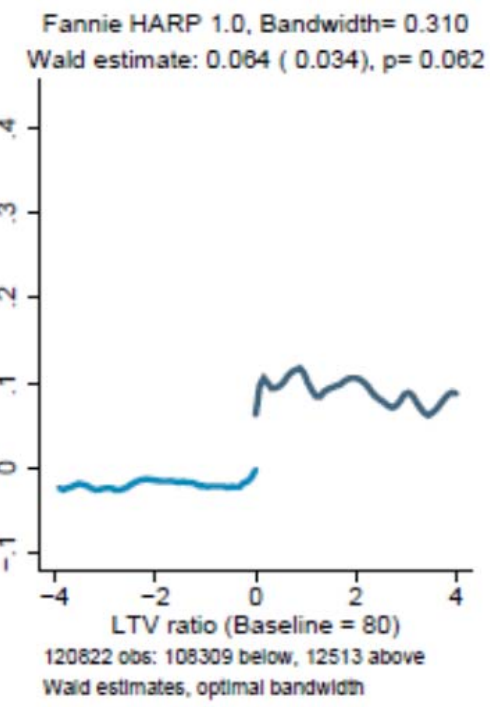

Fannie HARP 1.0, Bandwidth $=1.570$ Wald estimate: $0.102(0.015), p=0.000$

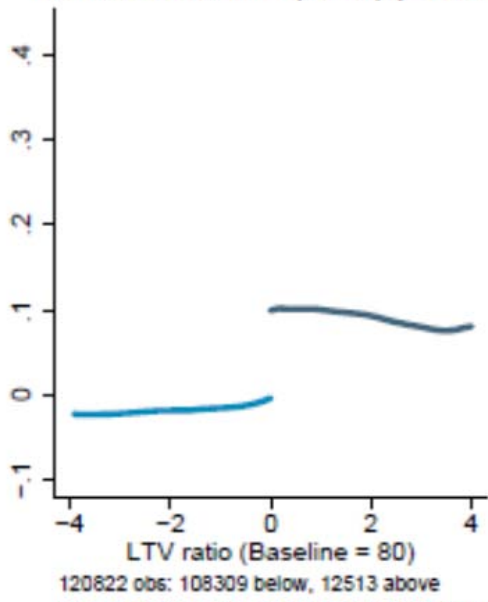
Waid estimates, 5 tmes the optimal banowidth
Fannie HARP 2.0, Bandwidth $=0.380$ Wald estimate: $0.142(0.038), p=0.000$

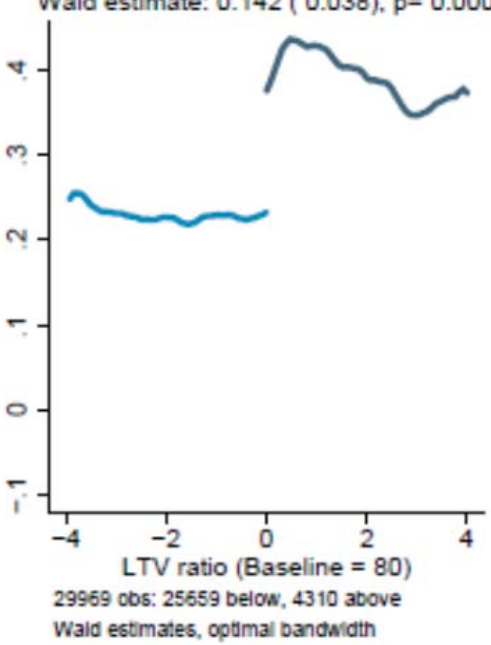

Fannie HARP 2.0. Bandwidth $=1.920$ Wald estimate: $0.184(0.015), p=0.000$

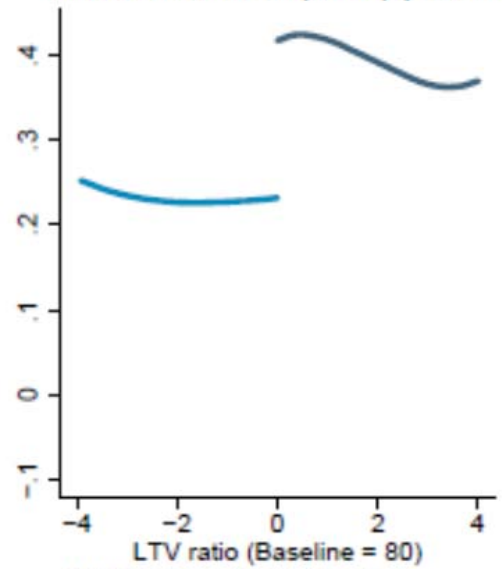
29969 obs: 25659 below, 4310 above Wald estmates, 5 times the optmal bandwith 


\section{Figure 6: Regression discontinuity in mortgage rates, various bandwidths}

The figure shows the results of fitting local linear regressions on either side of the LTV cutoff using a triangular kernel in each of the three regimes, defined as before. Within each of the regimes, the discontinuity estimates are presented for a range of bandwidth choices, with the optimal choice depicted by a red dot. The vertical whiskers show 95 percent confidence intervals.

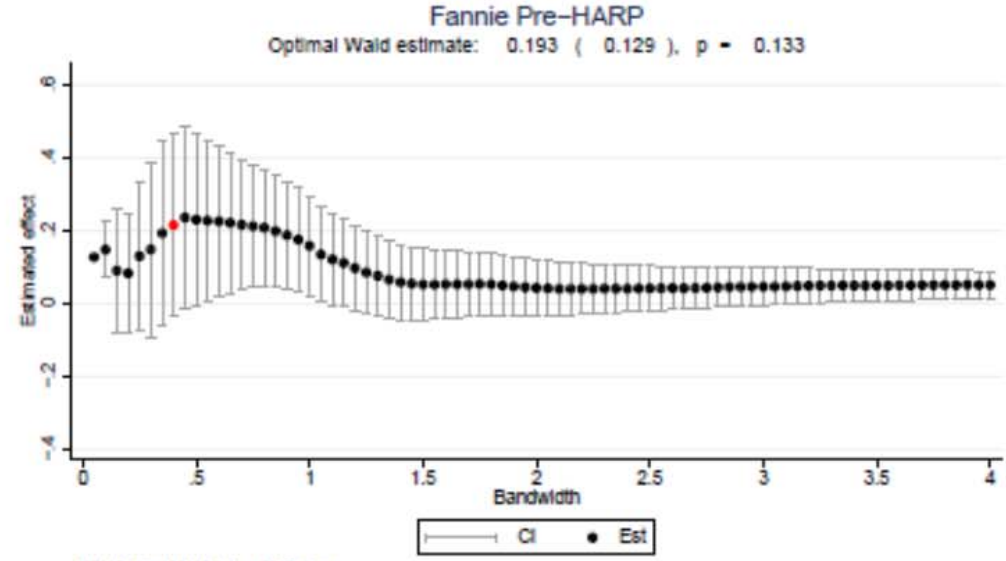

127962 ots 122195 telion 5207 nowe

Fannie HARP 1.0

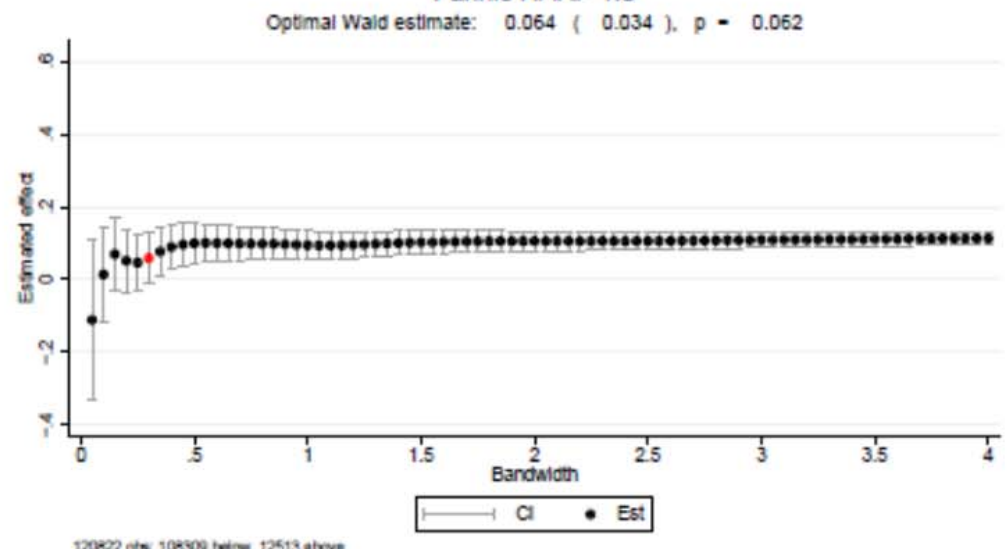

Fannie HARP 2.0

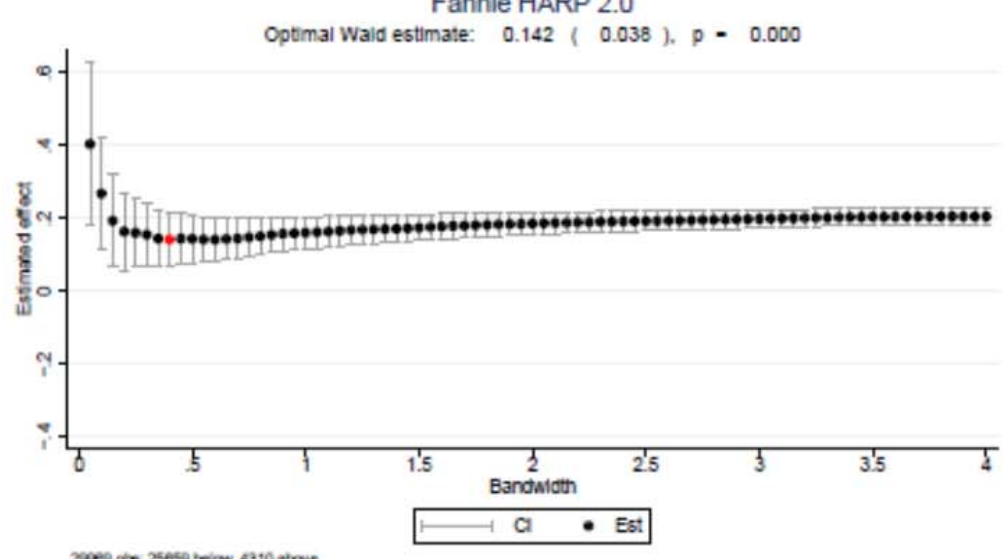

20000 dide $25 e 50$ beiow, ato atove 


\section{Figure 7: Regression discontinuity in mortgage rates, PLS loans}

The figure shows the results of fitting local linear regressions for PLS loans on either side of the LTV threshold using a triangular kernel in each of the three regimes, defined as before. The horizontal axis is expressed as deviations of LTV ratio from the HARP eligibility threshold of 80 . The vertical axis is expressed as the spread between the observed mortgage rates and the FHMLC survey reference rate. The top panel shows the results for the optimal bandwidth choice as described in Imbens and Kalyanaraman (2012). The bottom panel shows the results for the bandwidth that is 5 times the optimal. The sample is limited to 30 -year first-lien conventional FRM loans, with no prepayment penalties, collateralized by single-family owner-occupied properties, for FICO 740+ borrowers.
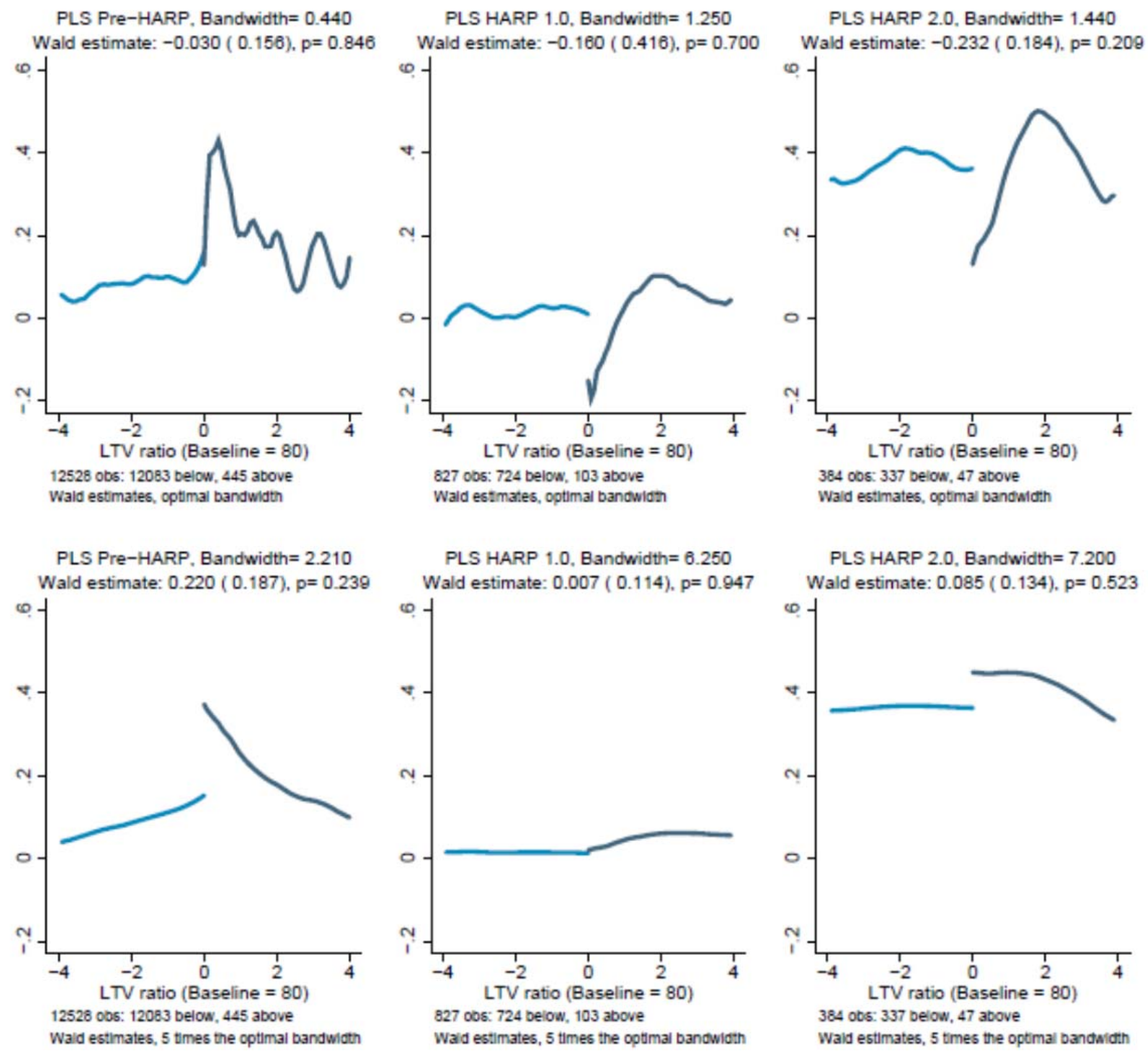


\section{Figure 8: Local smoothness in key borrower and loan characteristics}

The figure shows the results of fitting local linear regressions on either side of the LTV cutoff for FICO score, appraisal value, and loan documentation status. All variables and samples are defined as before. The figure shows results for the large bandwidth (5 times the optimal).

A. FICO score
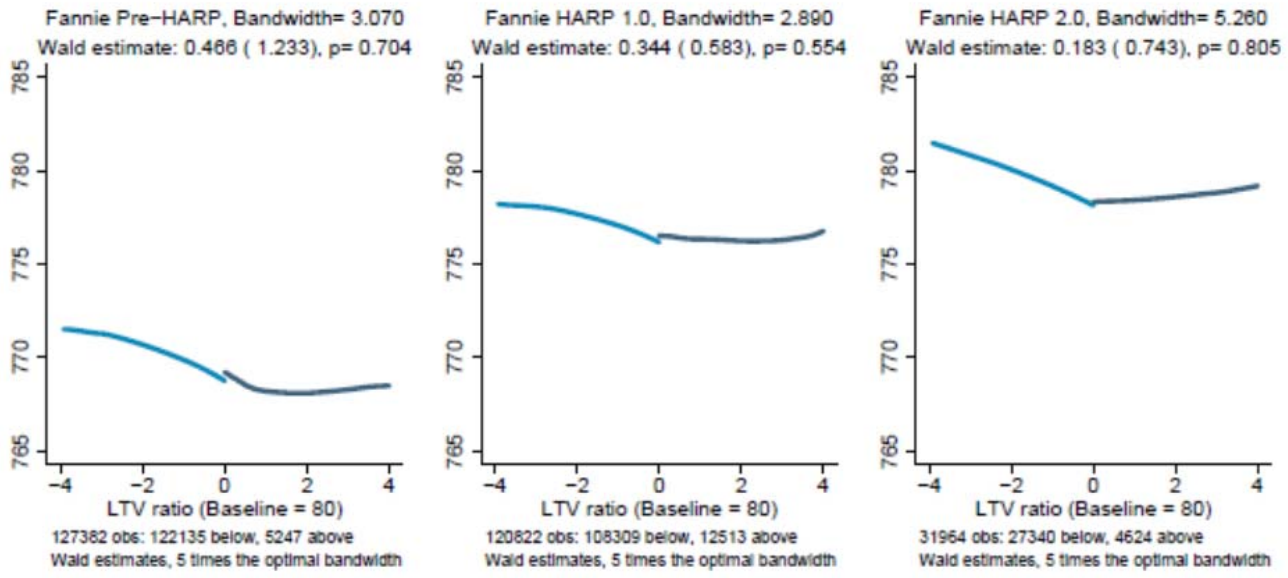

\section{B. Appraisal value (\$ thousands)}

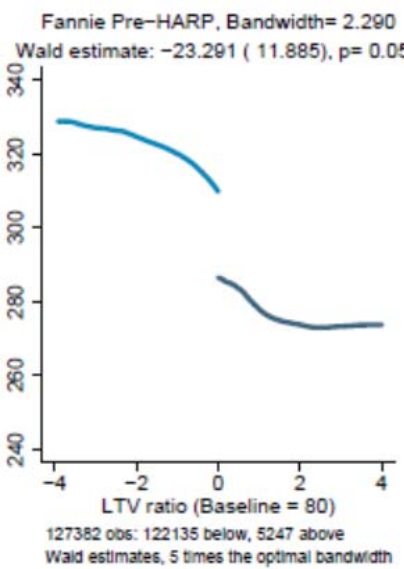

Fannie HARP 1.0. Bandwidth $=2.870$

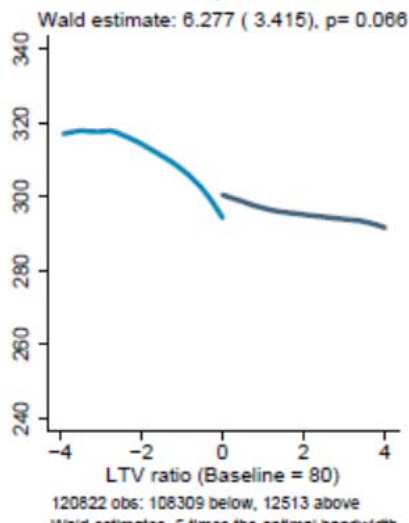

Fannie HARP 2.0 , Bandwidth $=2.780$

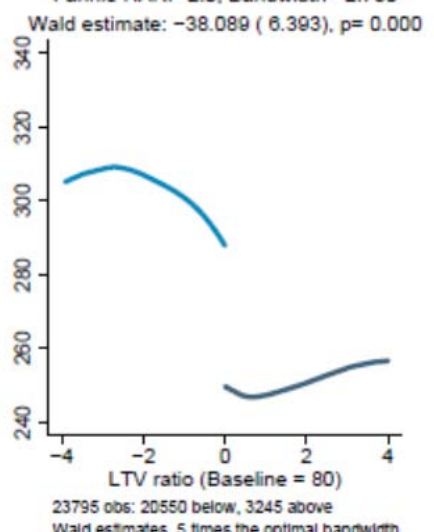

C. Share with full documentation status
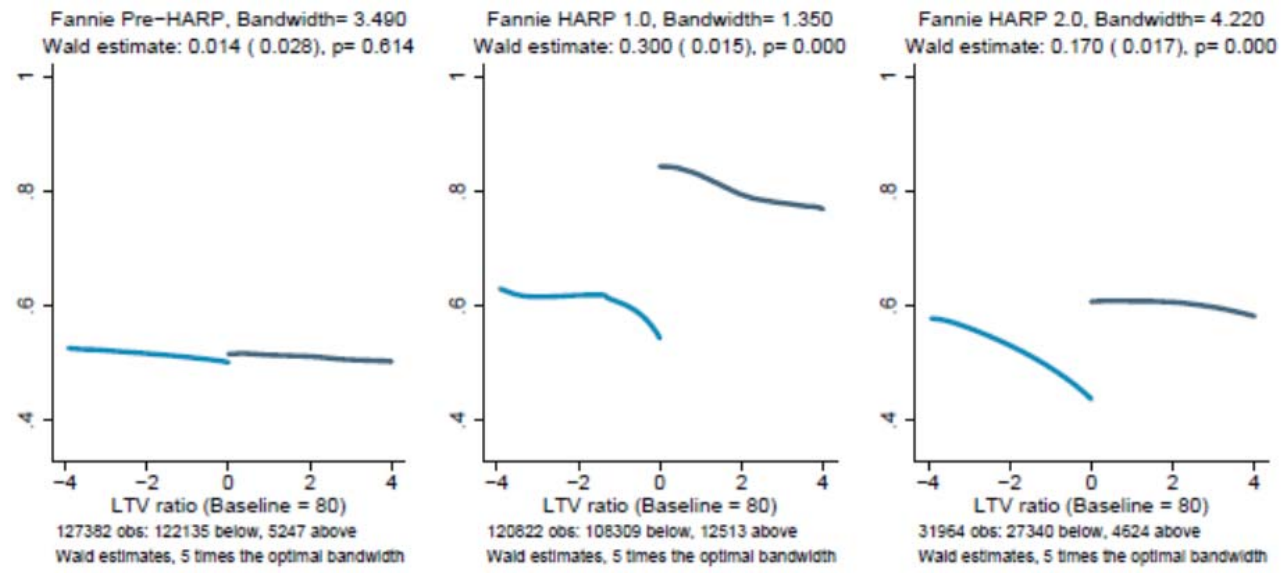


\section{Figure 9: Robustness of regression discontinuity results}

The figure shows RD estimates for the subsample that excludes loans with LTV $=80$ (the top panel) and loans with private mortgage insurance (the bottom panel). Otherwise, all of the variables and time periods are defined as before. Both panels show the results for the optimal bandwidth choice as described in Imbens and Kalyanaraman (2012).

A. Excluding mortgages with LTV 80
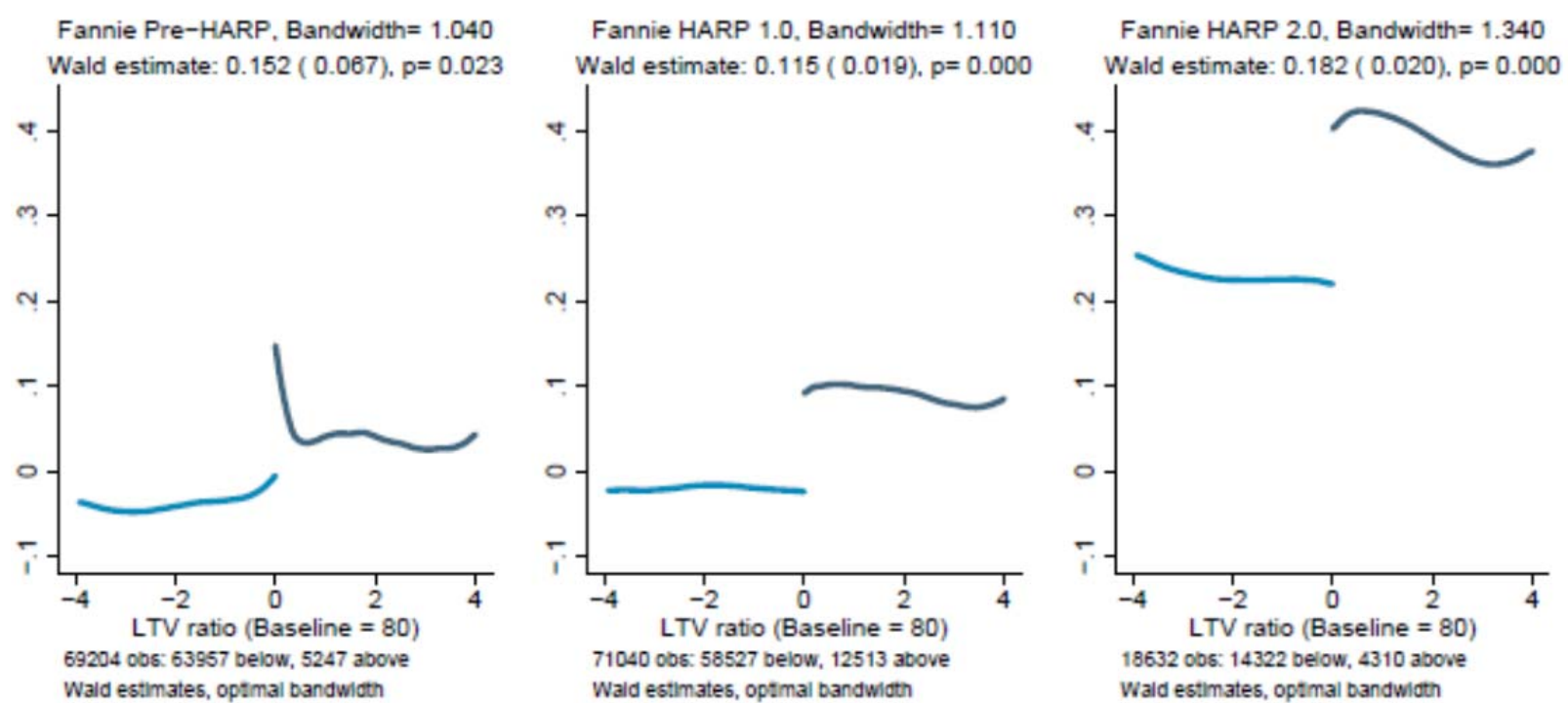

B. Excluding mortgages with PMI backing
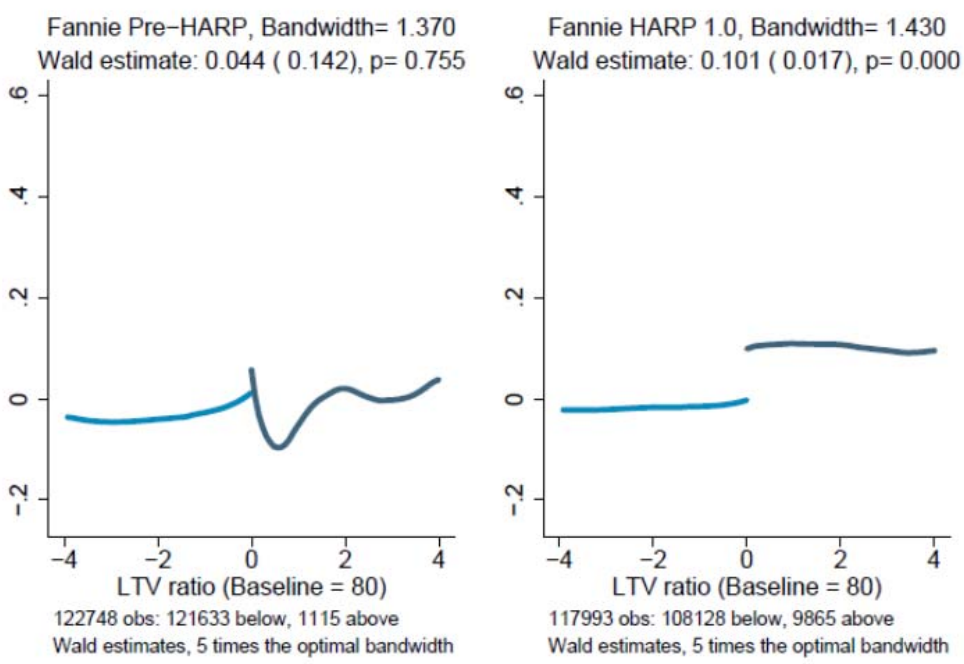

Fannie HARP 2.0, Bandwidth $=1.930$ Wald estimate: $0.179(0.016), p=0.000$

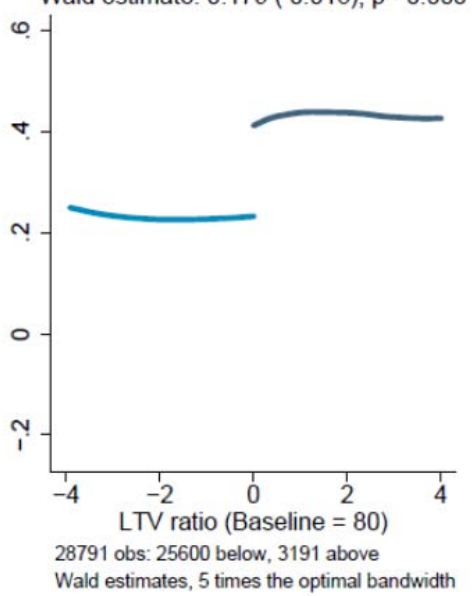

Sample: unmatched 30-yr refi FRMs, conventional, non-jumbo, single-family, first lien, owner-occupied, no pre-payment penalty, FICO 740 - 900 , less than 7 months 


\section{Working Paper Series}

A series of research studies on regional economic issues relating to the Seventh Federal Reserve District, and on financial and economic topics.

Corporate Average Fuel Economy Standards and the Market for New Vehicles

WP-11-01

Thomas Klier and Joshua Linn

The Role of Securitization in Mortgage Renegotiation

WP-11-02

Sumit Agarwal, Gene Amromin, Itzhak Ben-David, Souphala Chomsisengphet, and Douglas D. Evanoff

Market-Based Loss Mitigation Practices for Troubled Mortgages

Following the Financial Crisis

Sumit Agarwal, Gene Amromin, Itzhak Ben-David, Souphala Chomsisengphet, and Douglas D. Evanoff

Federal Reserve Policies and Financial Market Conditions During the Crisis

WP-11-04

Scott A. Brave and Hesna Genay

The Financial Labor Supply Accelerator

WP-11-05

Jeffrey R. Campbell and Zvi Hercowitz

Survival and long-run dynamics with heterogeneous beliefs under recursive preferences Jaroslav Borovička

WP-11-06

A Leverage-based Model of Speculative Bubbles (Revised)

WP-11-07

Gadi Barlevy

Estimation of Panel Data Regression Models with Two-Sided Censoring or Truncation Sule Alan, Bo E. Honoré, Luojia Hu, and Søren Leth-Petersen

Fertility Transitions Along the Extensive and Intensive Margins

Daniel Aaronson, Fabian Lange, and Bhashkar Mazumder

Black-White Differences in Intergenerational Economic Mobility in the US

WP-11-10

Bhashkar Mazumder

Can Standard Preferences Explain the Prices of Out-of-the-Money S\&P 500 Put Options?

Luca Benzoni, Pierre Collin-Dufresne, and Robert S. Goldstein

WP-11-11

Business Networks, Production Chains, and Productivity:

A Theory of Input-Output Architecture

WP-11-12

Ezra Oberfield

Equilibrium Bank Runs Revisited

WP-11-13

Ed Nosal

Are Covered Bonds a Substitute for Mortgage-Backed Securities?

WP-11-14

Santiago Carbó-Valverde, Richard J. Rosen, and Francisco Rodríguez-Fernández

WP-11-15

The Cost of Banking Panics in an Age before "Too Big to Fail"

Benjamin Chabot 


\section{Working Paper Series (continued)}

Import Protection, Business Cycles, and Exchange Rates:

Evidence from the Great Recession

WP-11-16

Chad P. Bown and Meredith A. Crowley

Examining Macroeconomic Models through the Lens of Asset Pricing

WP-12-01

Jaroslav Borovička and Lars Peter Hansen

The Chicago Fed DSGE Model

WP-12-02

Scott A. Brave, Jeffrey R. Campbell, Jonas D.M. Fisher, and Alejandro Justiniano

Macroeconomic Effects of Federal Reserve Forward Guidance

WP-12-03

Jeffrey R. Campbell, Charles L. Evans, Jonas D.M. Fisher, and Alejandro Justiniano

Modeling Credit Contagion via the Updating of Fragile Beliefs

WP-12-04

Luca Benzoni, Pierre Collin-Dufresne, Robert S. Goldstein, and Jean Helwege

Signaling Effects of Monetary Policy

WP-12-05

Leonardo Melosi

Empirical Research on Sovereign Debt and Default

WP-12-06

Michael Tomz and Mark L. J. Wright

Credit Risk and Disaster Risk

WP-12-07

François Gourio

From the Horse's Mouth: How do Investor Expectations of Risk and Return

Vary with Economic Conditions?

WP-12-08

Gene Amromin and Steven A. Sharpe

Using Vehicle Taxes To Reduce Carbon Dioxide Emissions Rates of

New Passenger Vehicles: Evidence from France, Germany, and Sweden

WP-12-09

Thomas Klier and Joshua Linn

Spending Responses to State Sales Tax Holidays

WP-12-10

Sumit Agarwal and Leslie McGranahan

Micro Data and Macro Technology

WP-12-11

Ezra Oberfield and Devesh Raval

The Effect of Disability Insurance Receipt on Labor Supply: A Dynamic Analysis

WP-12-12

Eric French and Jae Song

Medicaid Insurance in Old Age

WP-12-13

Mariacristina De Nardi, Eric French, and John Bailey Jones

WP-12-14

Fetal Origins and Parental Responses

Douglas Almond and Bhashkar Mazumder 


\section{Working Paper Series (continued)}

Repos, Fire Sales, and Bankruptcy Policy

WP-12-15

Gaetano Antinolfi, Francesca Carapella, Charles Kahn, Antoine Martin,

David Mills, and Ed Nosal

Speculative Runs on Interest Rate Pegs

The Frictionless Case

WP-12-16

Marco Bassetto and Christopher Phelan

Institutions, the Cost of Capital, and Long-Run Economic Growth:

Evidence from the 19th Century Capital Market

WP-12-17

Ron Alquist and Ben Chabot

Emerging Economies, Trade Policy, and Macroeconomic Shocks

WP-12-18

Chad P. Bown and Meredith A. Crowley

The Urban Density Premium across Establishments

WP-13-01

R. Jason Faberman and Matthew Freedman

Why Do Borrowers Make Mortgage Refinancing Mistakes?

WP-13-02

Sumit Agarwal, Richard J. Rosen, and Vincent Yao

Bank Panics, Government Guarantees, and the Long-Run Size of the Financial Sector:

Evidence from Free-Banking America

WP-13-03

Benjamin Chabot and Charles C. Moul

Fiscal Consequences of Paying Interest on Reserves

WP-13-04

Marco Bassetto and Todd Messer

Properties of the Vacancy Statistic in the Discrete Circle Covering Problem

WP-13-05

Gadi Barlevy and H. N. Nagaraja

Credit Crunches and Credit Allocation in a Model of Entrepreneurship

WP-13-06

Marco Bassetto, Marco Cagetti, and Mariacristina De Nardi

Financial Incentives and Educational Investment:

The Impact of Performance-Based Scholarships on Student Time Use

WP-13-07

Lisa Barrow and Cecilia Elena Rouse

The Global Welfare Impact of China: Trade Integration and Technological Change

Julian di Giovanni, Andrei A. Levchenko, and Jing Zhang

WP-13-08

Structural Change in an Open Economy

WP-13-09

Timothy Uy, Kei-Mu Yi, and Jing Zhang

The Global Labor Market Impact of Emerging Giants: a Quantitative Assessment

WP-13-10

Andrei A. Levchenko and Jing Zhang 


\section{Working Paper Series (continued)}

Size-Dependent Regulations, Firm Size Distribution, and Reallocation

WP-13-11

François Gourio and Nicolas Roys

Modeling the Evolution of Expectations and Uncertainty in General Equilibrium

WP-13-12

Francesco Bianchi and Leonardo Melosi

Rushing into American Dream? House Prices, Timing of Homeownership, and Adjustment of Consumer Credit

Sumit Agarwal, Luojia Hu, and Xing Huang

WP-13-13

The Earned Income Tax Credit and Food Consumption Patterns

WP-13-14

Leslie McGranahan and Diane W. Schanzenbach

Agglomeration in the European automobile supplier industry

WP-13-15

Thomas Klier and Dan McMillen

Human Capital and Long-Run Labor Income Risk

WP-13-16

Luca Benzoni and Olena Chyruk

The Effects of the Saving and Banking Glut on the U.S. Economy

WP-13-17

Alejandro Justiniano, Giorgio E. Primiceri, and Andrea Tambalotti

A Portfolio-Balance Approach to the Nominal Term Structure

WP-13-18

Thomas B. King

Gross Migration, Housing and Urban Population Dynamics

WP-13-19

Morris A. Davis, Jonas D.M. Fisher, and Marcelo Veracierto

Very Simple Markov-Perfect Industry Dynamics

WP-13-20

Jaap H. Abbring, Jeffrey R. Campbell, Jan Tilly, and Nan Yang

Bubbles and Leverage: A Simple and Unified Approach

WP-13-21

Robert Barsky and Theodore Bogusz

The scarcity value of Treasury collateral:

Repo market effects of security-specific supply and demand factors

WP-13-22

Stefania D'Amico, Roger Fan, and Yuriy Kitsul

Gambling for Dollars: Strategic Hedge Fund Manager Investment

WP-13-23

Dan Bernhardt and Ed Nosal

Cash-in-the-Market Pricing in a Model with Money and

Over-the-Counter Financial Markets

WP-13-24

Fabrizio Mattesini and Ed Nosal

An Interview with Neil Wallace

WP-13-25

David Altig and Ed Nosal 


\section{Working Paper Series (continued)}

Firm Dynamics and the Minimum Wage: A Putty-Clay Approach

WP-13-26

Daniel Aaronson, Eric French, and Isaac Sorkin

Policy Intervention in Debt Renegotiation:

Evidence from the Home Affordable Modification Program

WP-13-27

Sumit Agarwal, Gene Amromin, Itzhak Ben-David, Souphala Chomsisengphet, Tomasz Piskorski, and Amit Seru

The Effects of the Massachusetts Health Reform on Financial Distress

WP-14-01

Bhashkar Mazumder and Sarah Miller

Can Intangible Capital Explain Cyclical Movements in the Labor Wedge?

WP-14-02

François Gourio and Leena Rudanko

Early Public Banks

William Roberds and François R. Velde

WP-14-03

Mandatory Disclosure and Financial Contagion

WP-14-04

Fernando Alvarez and Gadi Barlevy

The Stock of External Sovereign Debt: Can We Take the Data at 'Face Value'?

WP-14-05

Daniel A. Dias, Christine Richmond, and Mark L. J. Wright

Interpreting the Pari Passu Clause in Sovereign Bond Contracts:

It's All Hebrew (and Aramaic) to Me

WP-14-06

Mark L. J. Wright

AIG in Hindsight

WP-14-07

Robert McDonald and Anna Paulson

WP-14-08

On the Structural Interpretation of the Smets-Wouters "Risk Premium" Shock

Jonas D.M. Fisher

Human Capital Risk, Contract Enforcement, and the Macroeconomy

WP-14-09

Tom Krebs, Moritz Kuhn, and Mark L. J. Wright

Adverse Selection, Risk Sharing and Business Cycles

WP-14-10

Marcelo Veracierto

Core and 'Crust': Consumer Prices and the Term Structure of Interest Rates

WP-14-11

Andrea Ajello, Luca Benzoni, and Olena Chyruk

The Evolution of Comparative Advantage: Measurement and Implications

WP-14-12 Andrei A. Levchenko and Jing Zhang 


\section{Working Paper Series (continued)}

Saving Europe?: The Unpleasant Arithmetic of Fiscal Austerity in Integrated Economies Enrique G. Mendoza, Linda L. Tesar, and Jing Zhang

WP-14-13

Liquidity Traps and Monetary Policy: Managing a Credit Crunch

WP-14-14

Francisco Buera and Juan Pablo Nicolini

Quantitative Easing in Joseph's Egypt with Keynesian Producers

WP-14-15

Jeffrey R. Campbell

Constrained Discretion and Central Bank Transparency

WP-14-16

Francesco Bianchi and Leonardo Melosi

Escaping the Great Recession

WP-14-17

Francesco Bianchi and Leonardo Melosi

WP-14-18

More on Middlemen: Equilibrium Entry and Efficiency in Intermediated Markets

Ed Nosal, Yuet-Yee Wong, and Randall Wright

Preventing Bank Runs

WP-14-19

David Andolfatto, Ed Nosal, and Bruno Sultanum

The Impact of Chicago's Small High School Initiative

WP-14-20

Lisa Barrow, Diane Whitmore Schanzenbach, and Amy Claessens

Credit Supply and the Housing Boom

WP-14-21

Alejandro Justiniano, Giorgio E. Primiceri, and Andrea Tambalotti

WP-14-22

The Effect of Vehicle Fuel Economy Standards on Technology Adoption

Thomas Klier and Joshua Linn

What Drives Bank Funding Spreads?

WP-14-23

Thomas B. King and Kurt F. Lewis

Inflation Uncertainty and Disagreement in Bond Risk Premia

WP-14-24

Stefania D'Amico and Athanasios Orphanides

Access to Refinancing and Mortgage Interest Rates:

WP-14-25

HARPing on the Importance of Competition

Gene Amromin and Caitlin Kearns 